Development of an optimum tracer set for apportioning emissions of individual power plants using highly time-resolved measurements and advanced receptor modeling

Project Report Report

John M. Ondov, PI

Professor of Chemistry

Gregory M. Beachley

Research Assistant

Department of Chemistry and Biochemistry, University of Maryland, College Park, MD 20742

jondov@umd.edu; 3014051859 (voice); 3013149121 (fax)

Reporting Period: $\quad$ Final Report

Date Report was Issued: $\quad$ August 8, 2008

DOE Award Number : $\quad$ DE-FG26-06NT42738

Recipient:

Department of Chemistry, University of Maryland 


\section{DISCLAIMER*}

"This report was prepared as an account of work sponsored by an agency of the United States Government. Neither the United States Government nor any agency thereof, nor any of their employees, makes any warranty, express or implied, or assumes any legal liability or responsibility for the accuracy, completeness, or usefulness of any information, apparatus, product, or process disclosed, or represents that its use would not infringe privately owned rights. Reference herein to any specific commercial product, process, or service by trade name, trademark, manufacturer, or otherwise does not necessarily constitute or imply its endorsement, recommendation, or favoring by the United States Government or any agency thereof. The views and opinions of authors expressed herein do not necessarily state or reflect those of the United States Government or any agency thereof." 


\section{EXECUTIVE SUMMARY}

In previous studies, 11 elements ( $\mathrm{Al}, \mathrm{As}, \mathrm{Cd}, \mathrm{Cr}, \mathrm{Cu}, \mathrm{Fe}, \mathrm{Mn}, \mathrm{Ni}, \mathrm{Pb}, \mathrm{Se}$, and $\mathrm{Zn}$ ) were determined in 30-minute aerosol samples collected with the University of Maryland Semicontinuous Elements in Aerosol Sampler (SEAS; Kidwell and Ondov, 2001, 2004; SEAS-II) in several locations in which air quality is influenced by emissions from coal- or oil-fired power plants. At this time resolution, plumes from stationary high temperature combustion sources are readily detected as large excursions in ambient concentrations of elements emitted by these sources (Pancras et al. ). Moreover, the time-series data contain intrinsic information on the lateral diffusion of the plume (e.g., $\sigma_{y}$ ), which Park et al. (2005 and 2006) have exploited in their Pseudo-Deterministic Receptor Model (PDRM), to calculate emission rates of $\mathrm{SO}_{2}$ and 11 elements (mentioned above) from four individual coal- and oil-fired power plants in the Tampa Bay area. In the current project, we proposed that the resolving power of source apportionment methods might be improved by expanding the set of maker species and that there exist some optimum set of marker species that could be used. The ultimate goal was to determine the utility of using additional elements to better identify and isolate contributions of individual power plants to ambient levels of PM and its constituents. And, having achieved better resolution, achieve, also, better emission rate estimates.

Work conducted. In this study, we optimized sample preparation and instrumental protocols for simultaneous analysis of 28 elements in dilute slurry samples collected with the SEAS with a new state-of-the-art Thermo-Systems, Inc., X-series II, Inductively Coupled Plasma Mass Spectroscopy (ICP-MS), and reanalyzed the samples previously collected in Tampa during the modeling period studied by Park et al. (2005) in which emission rates from four coal- and oilfired power plants affected air quality at the sampling site. In the original model, Park et al. (2005), included 6 sources. Herein, we reassessed the number of contributing sources in light of the new data. A comprehensive list of sources was prepared and both our Gaussian Plume model and PMF were used to identify and predict the relative strengths of source contributions at the receptor sites. Additionally, PDRM was modified to apply National Inventory Emissions, Toxic Release Inventory, and Chemical Mass Balance source profile data to further constrain solutions. Both the original Tampa data set $\left(\mathrm{SO}_{2}\right.$ plus 11 elements) and the new expanded data set $\left(\mathrm{SO}_{2}\right.$ plus 23 elements) were used to resolve the contributions of particle constituents and PM to sources using Positive Matrix Factorization (PMF) and PDRM.

Project Results are summarized below.

- Optimum Slurry Sample Preparation Method. Micro-wave and thermal oven heating protocols were tested using capped polypropylene sample collection and Teflon pressure vessels. Micro-wave treatment resulted in unequal heating of samples and 
afforded no benefit over thermal oven heating. After an exhaustive series of test, the optimal slurry sample preparation method was found to be heating in a thermal oven at $80^{\circ} \mathrm{C}$ for 2 days in polypropylene collection vials sealed in a pressure vessel maintained at a total pressure of $2.3 \mathrm{~atm}$. The protocols were tested on simulated slurry samples made from an as yet-to-be-released urban particle Standard Reference Material (UPSRM; National Institute of Standards and Technology, Gaithersburg, MD) and on two separate test slurries made by compositing SEAS slurry samples containing i) refractory particles from steel pipe and asphalt plants in Birmingham, AL; and ii) high levels of soot and organic carbon from a coke oven plant near Pittsburgh, PA.

- A total of 23 of 27 elements sought were determined in the test slurries and the Tampa samples after acidification and microwave heating. These included the 11 elements determined previously by GFAAZ (Al, $\mathrm{Cr}, \mathrm{Mn}, \mathrm{Fe}, \mathrm{Ni}, \mathrm{Cu}, \mathrm{Zn}, \mathrm{As}, \mathrm{Se}, \mathrm{Cd}$, and $\mathrm{Pb}$ ) and 16 additional elements: $\mathrm{Ag}, \mathrm{Ba}, \mathrm{Co}, \mathrm{La}, \mathrm{Sb}, \mathrm{V}, \mathrm{W}, \mathrm{Ca}, \mathrm{K}, \mathrm{Mg}, \mathrm{Na}$, and $\mathrm{Sr}$. Tin, U, Sm, and Ti could not be detected. Instrumental detection limits by ICPMS were uniformly better than those achieved by GFAAZ (Pancras et al., 2005) for all elements except Al and $\mathrm{Zn}$, for which the ICPMS DLs were $0.6 \mathrm{ppb}$ and $0.26 \mathrm{ppb}$, versus $0.1 \mathrm{ppb}$ and 0.04 ppb, respectively by GFAAZ.

- Recoveries for elements determined in test slurries prepared from an interim NIST Standard Reference Material (urban air particulate material) using the adopted heating method, exceeded $90 \%$ for most elements and were generally not significantly different from $100 \%$. Exceptions were $\mathrm{Ti}(<10 \%), \mathrm{Al}(54 \pm 15 \%), \mathrm{Cr}(65 \pm 18 \%)$, and $\mathrm{Fe}(67 \pm 6 \%)$, $\mathrm{La}(83 \pm 13 \%)$. Titanium results were too unreliable to be used. Nevertheless, Fe and Al determined by ICPMS in actual SEAS slurry samples were respectively $31 \pm 2 \%$ and $37 \pm 0.05 \%$ greater than those determined by GFAAZ, which suggest better performance by ICPMS on actual samples. It is noteworthy that Pancras et al. (2004), typically observed only $40 \%$ recovery for $\mathrm{Al}$ and Fe in SEAS samples analyzed by GFAAZ versus GFAAZ analysis of simultaneously collected filter samples prepared for analysis by total digestion in a sealed Teflon container. Substantial fractions of the masses of these elements are often associated with larger, difficult to dissolve particles excluded from GFAAZ analysis by transfer to the sampling cup, by sedimentation during the lengthy analysis period ( $\sim 45$ minutes), and during auto-pipetting of the sample into the furnace. Thus, a 30 to $\sim 40 \%$ increase in measured $\mathrm{Al}$ and $\mathrm{Fe}$ concentrations represents a significant improvement in the SEAS-Analysis methodology. Lastly, ICPMs results for $\mathrm{Cr}$ in the Tampa samples correlated well with, but differed substantially ( $\sim 3$-fold lower) from those by GFAAZ. The ICPMS results were better fit by PDRMs constrained by available NEI emission rates for $\mathrm{Cr}$.

- The method adopted allows analysis for 23 elements using $<3 \mathrm{~mL}$ slurry per sample with a total analysis time per sample of 3 minutes, after 24-hr heat treatment in-situ, in our thermal oven at a constant temperature of $85^{\circ} \mathrm{C}$.

- For the Tampa modeling period, analytical precision achieved by the ICMPS method was superior to the GFAAZ method for all of the 11 elements in determined by both methods, 
except for $\mathrm{Cu}$, for which precisions were $\%$ (GFAAZ) and 3\% (ICPMS).

- A manuscript describing the analysis protocol is in preparation for submission to Analytical Chemica Acta. (Beachley, G. M., and Ondov, Elevated Thermal Heating Preparation of Dilute Slurry Samples for Elemental Analysis by ICPMS).

- Sample Analyses. Twenty SEAS-II samples collected in Tampa, FL, were analyzed for 27 elements using the adopted protocols. In general, ICPMS and prior GFAAZ analysis results were in good agreement. However, owing to Argon Oxide ion interference and matrix effects, the precision of results for Fe and Cr by ICPMS was inferior to GFAAZ data, so the latter were used in the modeling exercises described below. Sixty samples collected in Baltimore, MD, were also analyzed but were not used in modeling.

- PMF Modeling Results. Using Positive Matrix Factorization as many as 6 factors could be identified resolved in the original 11-GFAAZ-element (plus $\mathrm{SO}_{2}$ ) data set for Tampa. These were identified as corresponding to the 6 sources used in PDRM modeling by Park et al. (2005), however, only factors identified as corresponding to the Manatee and to a lesser extent Gannon power plants were well resolved. Lower values of the sum-ofresiduals (Q) was obtained with 7 and 8 factor models, however, scaled residuals (for which the expectation factor is 1.0 ) for the 6 -factor model were all $<1.2$, indicating that all models were well fit.

When run with the original 11 and additional 12 ICPMS elements, the Q values for 6-, 7and 8-factor models increased owing to the additional number of species, but more importantly, $\mathrm{Q} / \mathrm{n}$ (where $\mathrm{n}=$ the number of species), increased, suggesting a poorer overall fit. PMF models were rerun after sequential removal of sets of elements characterized as having increasingly poor discriminating power. Correlations with $\mathrm{X} / \mathrm{Q}$ profiles did not substantially improve over those determined for the best of the core element data sets. Except for Manatee, resulting factor profiles correlated best with mixtures of X/Q profiles.

- PDRM Modeling Results. PDRM was found to be relatively insensitive to the addition of new elements into the input data matrix. Application of NEI data appears to be a promising method to develop constraints and to test the validity of both PDRM results and the NEI data. For example, Although ambient concentrations of As and Se were well correlated, NEI emission rates for As were inconsistent with PDRM results obtained using X/Qs constrained with continuous emission monitor data for $\mathrm{SO}_{2}$ and constraints based on NEI PM mass and elemental emission rate values and CMB profiles.

- This work is part of the requirements for Gregory Beachly's Ph.D., which we expect to be conferred in Fall 2008. 


\title{
DEVELOPMENT OF AN OPTIMUM TRACER SET FOR APPORTIONING EMISSIONS OF INDIVIDUAL POWER PLANTS USING HIGHLY TIME-RESOLVED MEASUREMENTS AND ADVANCED RECEPTOR MODELING
}

\author{
J. M. Ondov and G. M. Beachley \\ Department of Chemistry and Biochemistry, University of Maryland, College Park, MD \\ 20742
}

\section{INTRODUCTION}

In previous studies, 11 elements ( $\mathrm{Al}, \mathrm{As}, \mathrm{Cd}, \mathrm{Cr}, \mathrm{Cu}, \mathrm{Fe}, \mathrm{Mn}, \mathrm{Ni}, \mathrm{Pb}, \mathrm{Se}$, and $\mathrm{Zn}$ ) were determined in 30-minute aerosol samples collected with the University of Maryland Semicontinuous Elements in Aerosol Sampler (SEAS; Kidwell and Ondov, 2001, 2004; SEAS-II) in several locations in which air quality is influenced by emissions from coal- or oil-fired power plants. At this time resolution, plumes from stationary high temperature combustion sources are readily detected as large excursions in ambient concentrations of elements emitted by these sources (Pancras et al., 2006). Moreover, the time-series data contain intrinsic information on the lateral diffusion of the plume (e.g., $\sigma_{y}$ ), which Park et al. (2005 and 2006) have exploited in their Pseudo-Deterministic Receptor Model (PDRM), to calculate emission rates of $\mathrm{SO}_{2}$ and 11 elements (mentioned above) from four individual coal- and oil-fired power plants in the Tampa Bay area.

We proposed that the resolving power of source apportionment methods might be improved by expanding the set of maker species and that there exist some optimum set of marker species that could be used. In particular, $\mathrm{Ca}$ and other alkaline-earth elements could be expected to be useful in resolving the influence of the Big Bend coal-fired power plant, owing to its use of wet-lime scrubbers. The ultimate goal was to determine the utility of using additional elements to better identify and isolate contributions of individual power plants to ambient levels of PM and its constituents. And, having achieved better resolution, achieve, also, better emission rate estimates.

Pursuant to these goals, we optimized sample preparation and instrumental protocols for simultaneous analysis of 28 elements in dilute slurry samples collected with the SEAS with a new state-of-the-art Thermo-Systems, Inc., X-series II, Inductively Coupled Plasma Mass Spectroscopy (ICP-MS), and reanalyzed the samples previously collected in Tampa during the modeling period studied by Park et al. (2005) in which emission rates from four coal- and oilfired power plants affected air quality at the sampling site. In the original model, Park et al. (2005), included 6 sources. However, PDRM was run only with $\mathrm{SO}_{2}$ and the 11-element data set, i.e., PM mass concentrations were not included. Moreover, there was a 30-minute discrepancy between the model's prediction of arrival time of the plume from, Manatee, one of the two major oil-fired power plants in the study domain, and the time at which an excursion of $\mathrm{Ni}$, thought to be an excellent marker of PM emitted from oil-fired power plants, was observed in the ambient concentration data. In addition, there appears to have been an additional source (or sources) of $\mathrm{Cu}$ at 14:00, Fe and $\mathrm{Mn}$ at 15:00, $\mathrm{Zn}$ at 16:30, and $\mathrm{Fe}$ at 17:00; and Fe, along with $\mathrm{Pb}$ and $\mathrm{Cu}$, was substantially over predicted from 18:00 to 19:00. Herein, we reassessed the number of contributing sources in light of the new elemental data, and also include estimates of ambient 
mass concentrations based on major species. A comprehensive list of sources was prepared and both our Gaussian Plume module (PDRM-GPM) and PMF were used to identify and predict the relative strengths of source contributions at the receptor sites. Both the original Tampa data set ( $\mathrm{SO}_{2}$ plus 11 elements) and the new expanded data set $\left(\mathrm{SO}_{2}\right.$ plus 23 elements) were used to resolve the contributions of particle constituents and PM to sources using Positive Matrix Factorization (PMF) and PDRM.

\section{EXPERIMENTAL METHODS}

\section{Sample Preparation Methods Development}

Direct slurry sample analysis has been reported for ICPMS (Santos and Nobrega, 2006; Coedo et al., 2000; Gregoire et al., 1994). However, initial tests with our instrument showed that significant concentration increases (10-30\%) were observed for $\mathrm{Al}, \mathrm{Ca}, \mathrm{Fe}, \mathrm{K}, \mathrm{Ni}$, and $\mathrm{Ti}$ in samples reanalyzed by ICPMS after storage for 20 days in an acidic environment. Such behavior is attributed to losses of particles to the walls of the sample vials and peristaltic pump tubing and statistical sampling issues for discrete particles, the effects of which are all reduced by long storage times which allow for slow leaching and/or dissolution of refractory constituents, e.g., crustal dust, in the slurry samples. Owing to these problems, we performed an extensive series of sample preparation tests to determine the optimum temperature, acid concentration, and heating temperature for SEAS samples commensurate with optimum sample "throughput,' maximum recovery of analytes, and minimum contamination. These tests were conducted using a surrogate slurry made from a yet-to-be-released NIST atmospheric fine particle Standard Reference Material, for which high-quality elemental constituent analyses area available, and test slurries prepared by compositing SEAS samples collected in two different locations to provide a challenging range of sample and matrix types. Specifically, these were samples containing highly refractory aerosol particles collected near Birmingham, AL, and soot-rich samples collected down-wind of a coke oven located near Pittsburgh. These are described in greater detail in Appendix B.

To eliminate the possibility of analyte losses or contamination, samples were processed directly in their original polypropylene collection vials. To prevent sample loss during heating, the vials were heated with their push-tight caps installed. Initial tests were made using micro-wave heating, however, owing to the different amounts of sample in each vial and spatially nonuniform microwave intensity, pressure buildup leading to ejection of vial tops and slurry material could not be reliably controlled. To prevent the cap ejection during subsequent heatingtemperature and duration tests, the capped vials were placed in a pressurized container inside a thermal oven. The maximum safe operating pressure of the vessel was $2.3 \mathrm{~atm}$, which limited the maximum heating temperature to $85^{\circ} \mathrm{C}$. The tests revealed that analytical yield increased very little after 44 hours at an acid strength of $0.2 \%$. Increasing acid strength to $0.5 \%$ was ineffective, and at $\%$, contamination became unacceptable for several important elements (Al, As, Ca, Cd, Mg, Se, Ti, and Zn). Therefore, samples analyzed in this study were acidified with sufficient high-purity nitric acid to achieve a concentration of $0.2 \%$ and heated for 44 hours in our thermal oven at $85^{\circ} \mathrm{C}$ under an external pressure of $2.3 \mathrm{~atm}$.

Recoveries for elements determined in test slurries prepared from an interim NIST Standard Reference Material (urban air particulate material) using the adopted heating method, exceeded 
90\% for most elements and were generally not significantly different from 100\% (see Table B1). Exceptions were $\mathrm{Ti}(<10 \%), \mathrm{Al}(54 \pm 15 \%), \mathrm{Cr}(65 \pm 18 \%)$, and $\mathrm{Fe}(67 \pm 6 \%), \mathrm{La}(83 \pm 13 \%)$. Titanium results were too unreliable to be used. Nevertheless, Fe and Al determined by ICPMS in actual SEAS slurry samples were respectively $31 \pm 2 \%$ and $37 \pm 0.05 \%$ greater than those determined by GFAAZ, which suggest better performance by ICPMS on actual samples. It is noteworthy that Pancras et al. (2004), typically observed only $40 \%$ recovery for $\mathrm{Al}$ and $\mathrm{Fe}$ in SEAS samples analyzed by GFAAZ versus GFAAZ analysis of simultaneously collected filter samples prepared for analysis by total digestion in a sealed Teflon container. Substantial fractions of the masses of these elements are often associated with larger, difficult to dissolve particles. We believe these can be excluded from GFAAZ analysis by transfer to the sampling cup, by sedimentation during the lengthy analysis period ( $\sim 45$ minutes), and during autopipetting of the sample into the furnace. Thus, a 30 to $40 \%$ increase in measured $\mathrm{Al}$ and Fe concentrations represents a significant improvement in the SEAS-Analysis methodology.

\section{Field Study Domain and Sampling}

As described by Park et al. (2005), $\mathrm{PM}_{\text {fine }}$ samples were collected at 30-minute intervals at the BRACE sampling site in Sydney, FL (near Tampa), with the University of Maryland Semicontinuous Elements in Aerosol Sampler (SEAS; Kidwell and Ondov, 2001 and 2004) during an 8.5-hour sampling period on May 13, 2002, during which the mean wind direction shifted roughly from south to west (wind angles 200 to $270^{\circ}$ ), placing the sampling site down wind of sources contained in the $90^{\circ}$ quadrant southeast of the site, wherein lie 4 major power plants and several much smaller sources of $\mathrm{SO}_{2}$ and PM (see Figure 1). A complete list of sources compiled for the Tampa area is provided in Appendix A.

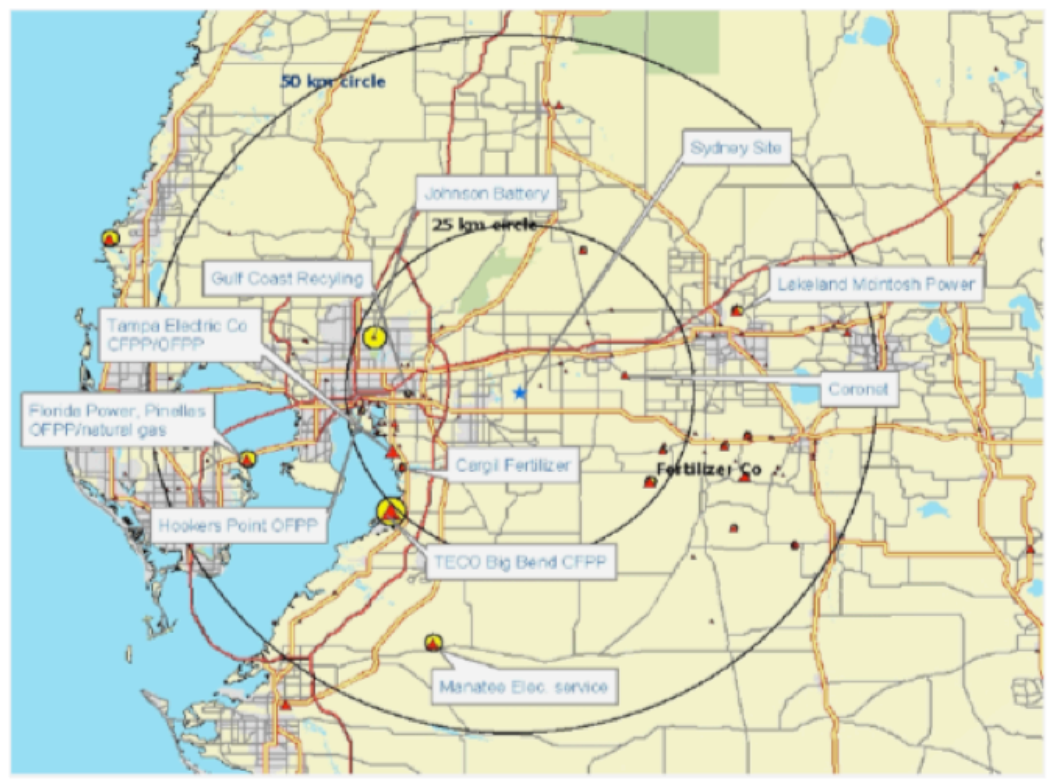

Figure 1. Map of Tampa area showing the location of the sampling site in Sydney and the larger air pollution sources in the area.

Two-minute averaged surface meteorological observations were available from the NOAA vertical profiling site at Sydney (NOAA ETL, 2003). One-minute $\mathrm{SO}_{2}$ measurements, made 
during the study period using the Federal Reference Method "pulsed fluorescence analyzer," were available from the BRACE website.

PM2.5 mass concentration measurements made with a Tapered Element Oscillating Microbalance were not available for our study period. Instead, ambient mass was (crudely) estimated as the sum of major ionic species (ammonium, sulfate, nitrate, and chloride ) available from the BRACE database.

\section{Sample Preparation and Analyses.}

The samples collected by Park et al. (2005) were analyzed for 11 elements (Al, As, Cd, Cr, Cu, $\mathrm{Fe}, \mathrm{Mn}, \mathrm{Ni}, \mathrm{Pb}, \mathrm{Se}$, and $\mathrm{Zn}$ ) by multielement Graphite-Furnace Atomic Absorption Spectroscopy with Zeeman background correction (GFAAZ) as described by Pancras et al., 2004. Prior to GFAAZ analyses, Pancras et al. (2004) added high-purity nitric acid to achieve a final added concentration of $0.2 \%$ and sonicated each sample for $30 \mathrm{~min}$ to suspend and stabilize the particles in suspension. Herein, those same samples were analyzed for the 11 elements previously determined, plus 14 additional elements using Inductively-Coupled Plasma Mass Spectrometry (ICPMS), after microwave heating for 10 sequential 30-sec cycles, followed by a 15 minute cooling period, and another 4 30-second heating cycles.

\section{Modeling Methods and Source Identification}

We used Postive Matrix Factorization (PMF; Paatero and Tapper, 1994; and Paatero,1997) and the Pseudo-Deterministic Receptor Model (PDRM) to investigate the number of sources needed to explain the time series excursions and the influence of employing additional numbers of marker species on our ability to resolve the contributions of particles and their constituents to the four major utility power plants. Both methods solve the basic bilinear equation of the form:

$$
Y_{i, t}=\sum_{s=1}^{n} A_{i, s} B_{s, t}+e_{i, t}, \quad \text { Equation } 1 .
$$

where $i, t$, and s are indices for the numbers of constituents (i.e., pollutants), samples (or time steps), and sources, respectively, and $\mathrm{Y}$ is the matrix of measured ambient concentrations whose temporal fluctuation patterns are to be fit.

In PDRM Equation 1 is cast in terms of the products of emission rates (ER, g/s) and dispersion factors $\left(\mathrm{X} / \mathrm{Q}, \mathrm{s} / \mathrm{m}^{3}\right)$, i.e., $\mathrm{ER}=\mathrm{A}$ and $\mathrm{X} / \mathrm{Q}=\mathrm{B}$. The MatLab "lsqcurvefit" function is used as the solver. A Gaussian plume model (PDRM-GPM) is used to provide initial guesses for the dispersion terms (one for each source) and to set constraints on the solutions to allow for inaccuracies in the model. Input parameters for the Gaussian plume model include wind direction, source to receptor distances, the "station" angle for each source (Polar coordinate angle of the line connecting the source and sampling site, as measured from due North), plume transport speed, and the vertical and horizontal dispersion terms ( $\sigma_{z}$ and $\sigma_{y}$, respectively). The vertical and horizontal dispersion terms were calculated by a "Plume" module in the PDRM as described by Park et al. (2005). Additional data required include stack height, and exit gas velocities and temperatures for the modeled sources are those obtained by Park et al. (2005) for the 6 sources modeled in their work. Stack data for additional sources was obtained from the National Emission Inventory (2002). Herein, we used the PDRM as configured by Park et al. 
(2005), but with various different combinations of ambient concentration data. These encompassed the original set of 11 elements and $\mathrm{SO}_{2}$ measurements, newly derived estimates of PM mass concentration, and the additional elements developed from the ICPMS reanalyses. Because $\mathrm{SO}_{2}$ emission rates for the 4 utility power plants were derived from CEM data, we constrained solutions for these to lie within $+/-5 \%$ of these values. As configured, PDRM apportions mass to only the specified sources. Therefore, atmospheric concentrations used in PDRM were corrected for background by linear interpolation between the lowest values at the beginning and end of the sampling interval, as done by Park et al. (2005).

As configured, PDRM is applicable only to cases in which the mean wind direction remains constant over the transport time. However, as shown in Park et al. (2005), a rapid shift in the mean wind direction (from $\sim 200$ to $\sim 250^{\circ}$ ) occurred just after 12:00 PM. Between 15:30 and 18:30, surface winds remained at $\sim 253 \pm 5^{\circ}$.

To account for this shift, station angles were shifted accordingly to reflect the true angle at which the plume from each arrived at Sydney, and the plume travel distance (used in computing estimates of $\sigma_{\mathrm{y}}$ and $\sigma_{\mathrm{z}}$ ) was likewise adjusted to reflect the true path. Herein, these same adjustments were made to the PDRM inputs, however, based on a more rigorous back trajectory analysis, 4.8 and $4.0^{\circ}$ were subtracted from the surface wind directions observed during the first two sampling intervals (12:00 and 12:30) to obtain 185 and $196^{\circ}$. This resulted in a much better fit between the Manatee X/Q profile and the $\mathrm{Ni}$ (and V) excursion in the concentration time series data.

In PMF, A is defined as the matrix of Abundances of the $\mathrm{i}$ species in material emitted from the $\mathrm{s}$ sources and the $\mathrm{B}$ is defined as the matrix of contributions of each of the s sources to the sum of all species. If the sum of the mass concentrations of all species in the A matrix were equal to the observed mass concentration in the ambient samples, then the B matrix would contain the mass concentrations (e.g., of PM in units of $\mu \mathrm{g} / \mathrm{m}^{3}$ ). However, the data are normalized and may include both particulate-borne and gaseous pollutants in different units, and they need not sum to the total mass either particulate or gaseous pollutants, which is true in our case. For this reason, we define the elements of the B matrix to be in units of "pseudo mass." Mass concentrations in true mass units (e.g., for PM), were obtained by multilinearly regressing ambient mass concentration estimates (described above) against the components of the B matrix.

PMF solves equation in a Factor Analysis sense by least squares minimization of sum of the weighted residuals. This is, by minimizing the value of Q defined as

$$
Q=\sum_{i=1}^{p} \sum_{t=1}^{q}\left(\frac{e_{i, t}}{s_{i, t}}\right)^{2} \text { where } \mathrm{s}_{\mathrm{i}, \mathrm{t}} \mathrm{s} \text { are the weights. Ideally, the mean value of individual }
$$

$\mathrm{e}_{\mathrm{i}, \mathrm{t}} / \mathrm{s}_{\mathrm{i}, \mathrm{t}} \mathrm{s}$ should be 1 . Thus the value of $\mathrm{Q}$ will depend on the number of numbers of samples $(\mathrm{q})$ and species (p) input to the model. All models herein contained the same number of samples, but the number of species ranged from 12 to 27 . Therefore, we divided Q by the number of species input to the model. 
The weights are typically taken to be the uncertainty in the measured ambient concentration of species $i$ at time $t$. However, this practice often requires arbitrary error "inflation" for some of the marker species to achieve plausible solutions. We argue that the minimum uncertainty, i.e., if a source's ambient concentration signal is perfectly resolved from all other sources, except for an underlying, more slowly changing background signal, is the uncertainty in the result after background subtraction. For these reasons, uncertainties used in PMF are those propagated after background subtraction as described above.

PMF is often run in "robust" mode, in which in which values of $e_{i, t}$ that exceed their corresponding uncertainties $\left(\mathrm{s}_{\mathrm{i}, \mathrm{t}}\right)$ by a specified factor are down-weighted by increasing the latter, the objective being to eliminate outliers. This improves the fit, but can eliminate legitimate factors. Therefore, PMF models were run in non-robust mode, choosing instead to observe the Q matrix graphically as numbers of factors was varied.

Identification and Assignment of Sources. In both PMF and PDRM, the number of factors (PMF) or sources (PDRM) sought must be specified by the user. In PDRM individual sources must be explicitly identified. In PMF, the actual sources must be inferred from the compositions of individual factors (A matrix) and the temporal distributions of their strengths (B matrix) in correlation with wind directions and source location. Herein, factor identifications were also made by correlating the B matrix with the PDRM X/Q matrix (i.e., 1 set for each source). Uncertainties in the ambient concentration data cause co-mingling of sources, even when wind directions (and back trajectories) would obviate their influence. In the PDRM, the exponential term of the Gaussian Plume model effectively eliminates contributions from sources for which transport wind angle deviates substantially from the station angle.

Park et al. (2005) originally constructed a 6-source model to explain the GFAAZ and $\mathrm{SO}_{2}$ data set. These encompassed 4 major utility power plants (Manatee, Big Bend, F. J. Gannon, and Bartow) and two small industrial sources, Gulf Coast recycling and the Cargill fertilizer plants. Herein, we ran Park et al.'s (2005) original 6-soruce PDRM, and 7, 8, and 9- source PDRM, models to account for some inadequacies in their fits for some of the elements and for new sources identified with the additional elements provided by ICPMS. Candidate sources were drawn from a list of area sources obtained from the Florida Department of Environmental protection (Appendix A). To assess the suitability of candidate sources for inclusion in the model, temporal profiles of X/Q and, for those for which emission rate estimates were available, induced ground-level concentration profiles were calculated and correlated with the measured ambient concentration (versus time-of-day) profiles. Emission data included were those reported in Park et al. (2005) for the original 6 sources, and additional data as available from the Florida Department of Environmental Protection's Air Resource Management System (web accessible Pobtained from the EPA's Clean Air Markets Emissions Data and Compliance Report web page (USEPA, 2003). As described below, 3 additional source types were considered in the current study.

Characteristics of the 6 sources modeled by Park et al. are described immediately below. Their locations are shown in Figure 1. Descriptions of the additional source types follow immediately thereafter. 
Description of the 6-sources Modeled by Park et al (2005).

Manatee and Bartow. Manatee and Bartow are both oil-fired power plants, operated by Florida Power and Light, and Progress Energy, respectively. Both are located at comparable distances from the sampling site (41 and $38 \mathrm{~km})$, and their $\mathrm{SO}_{2}$ emission rates $(110$ and $1140 \mathrm{~g} / \mathrm{s})$ were also comparable during the study period. Annual PM emission rates reported for Manatee (9470 metric tons/year) are, however, nearly 4-fold larger than those for Bartow (2600 metric tons/year). Manatee's station angle with respect to Sydney is $196^{\circ}$ and is spatially well separated from Bartow (station angle $253^{\circ}$ ).

F. J. Gannon and Big Bend. Both Gannon (1200 MW) and Big Bend ( 1800 MW) are coalfired power plants operated by Tampa Electric Company (TECO). Gannon is equipped with an Electrostatic precipitator (ESP), while Big Bend is equipped with both an ESP and a wet (forced oxidation lime) scrubber. Both burn bitmunous coal. $\mathrm{SO}_{2}$ emissions from the Gannon plant $(2600 \mathrm{~g} / \mathrm{s})$ were the largest of the 4 utility power plants, while those from Big Bend were the smallest (300 g/s) during the study period. Reported (data available in August 2003) annual PM emission rates (6267 and 7591 ton/yr respectively) for these plants were comparable, but somewhat less than that reported for Manatee (9470 ton/yr).

Two- to 10-fold enrichments in emissions of W, V, U, As, Fe, and Mn in emitted particles have been reported for a wet scrubber (Ondov et al., 1981).

Note that Gannon and Bartow lie at nearly the same station angle (251 and $\left.253^{\circ}\right) . \mathrm{SO}_{2}$ and $\mathrm{PM}$ emission rates reported for Gannon are $\sim$ twice those reported for Bartow, and Gannon is nearly half the distance from Sydney as Bartow. Their stack heights are comparable, thus, we expect Gannon's influence to be substantially greater than that of Bartow for PM. But this is not necessarily true for transition and heavy metals. For example, concentrations of $\mathrm{V}$ and $\mathrm{Ni}$ reported for particles emitted from Oil-fired Power Plants are in the 1 to $2 \%$ range (Olmez et al., 1988), whereas those reported for coal-fired plants are more typically $\sim 0.03 \%$ (Ondov et al., 1979).

Industrial Sources. The Cargill plant burns sulfur to make sulfuric acid. Natural gas is used for all other heating operations. Its reported $\mathrm{SO}_{2}$ and $\mathrm{PM}$ emission rates are $\sim 3,400(108 \mathrm{~g} / \mathrm{s})$ and $288(9 \mathrm{~g} / \mathrm{s})$ metric tons/year, respectively. Cargill is located $25 \mathrm{~km}$ from Sydney at a station angle of $235^{\circ}$.

The Gulf Coast plant (station angle, $269^{\circ}$ ) recycles lead batteries to produce $\mathrm{Pb}$ ingots mixed with $\mathrm{Sb}, \mathrm{Al}, \mathrm{Sn}$, or other metals. This facility operates two coke-fired blast furnace equipped with bag-houses for collection of PM emissions before discharge through $46 \mathrm{~m}$ stacks. The blast furnace feeds molten lead into open topped molds. Material captured by the baghouses is sent to a flash agglomeration furnace to be liquefied and the molten material poured into open crucibles and then crushed before being transferred to the blast furnace feed hoppers for lead recovery. The cooled lead "buttons" are re-melted and mixed with additives, which include $\mathrm{Sb}, \mathrm{Al}$, and $\mathrm{Sb}$, depending on desired product composition. Its $\mathrm{SO}_{2}$ and $\mathrm{PM}$ emission rates are reported to be only $487(15 \mathrm{~g} / \mathrm{s})$ and 26 metric tons/year, respectively. However, this plant is located only 15 
$\mathrm{km}$ from Sydney and it is expected to be a substantial source of $\mathrm{Pb}, \mathrm{Al}$, and $\mathrm{Sb}$. Stack heights for both these plants are $46 \mathrm{~m}$, i.e., much lower than the Utility Plants, and emission of fumes from molten metal pouring operations occurs nearly at ground level.

\section{Additional Sources Modeled}

With the 6-source model, Park et al. (2005) could not explain a sharp excursion in the concentration of $\mathrm{Cu}$ at 14:00, nor an excursions in $\mathrm{Zn}$ at 16:30. Moreover, a large excursion in Fe occurring at 15:00 was believed to be contamination and was removed from the modeled data set. Herein, we included three additional sources in PDRM models in an attempt to account for these excursions, as suggested by surface wind back trajectories, shown in Figure 3.

Tampa Armature Works. Tampa (station angle 261.0 $0^{\circ}$ distance, $13.9 \mathrm{~km}$ ) Armature Works operates a state-of-the-art manufacturing facility for fabrication of electronic parts. Point source emissions include an electrical windings reclamation incinerator. PDRM predicts the maximum influence of this source to occur between 14:00 and 15:00. A relatively small excursion in $\mathrm{Cu}$ along with As, and $\mathrm{Se}$, and possibly $\mathrm{Pb}$ was observed at 14:00.

Shipyards. Three major shipyard (Tampa Shipyard, Gulf Marine, and International Ship) lay $20 \mathrm{~km}$ upwind of the sampling site, between 260 and $267^{\circ}$. All three are major facilities and service large ocean-going vessels. The Tampa shipyard (station angle, $259.8^{\circ}$; distance, 21.7 $\mathrm{km}$ ) is cited as one of the busiest in the Southeast. Gulf marine lies at a station angle of $263.6^{\circ}$ at a distance $21.2 \mathrm{~km}$. These shipyards provide maintenance and repair of vessels of all sizes and encompass large-scale fabrication of parts and assemblies involving steel cutting and welding, slag abrasive blasting (for removal of scale, rust, and paint from ship hulls and other steel surfaces), and surface coating. International Ship (station angle, $266.4^{\circ}$; distance $21.1 \mathrm{~km}$ ) repairs and modify large and small ships, motors, and boilers and in addition to 5 dry docks, they maintain a $25,000-\mathrm{ft}^{2}$ fabrication area which is only partially covered. International ship also advertises water blasting (up to $35,000 \mathrm{psi}$ ), and steel fabrication and replacement Abrasive blasting materials typically used (Reed Minerals "Black Beauty) contain 48.8\% $\mathrm{SiO}_{2}, 21 \%$ $\mathrm{Al}_{2} \mathrm{O}_{3}, 19.08 \% \mathrm{Fe}_{2} \mathrm{O}_{3}, 6.0 \% \mathrm{CaO}, 1.7 \% \mathrm{~K}_{2} \mathrm{O}, 92 \% \mathrm{TiO}_{2}, 0.90 \% \mathrm{MgO}$, and $0.62 \% \mathrm{Na}_{2} \mathrm{O}$.

Incinerators. As shown in Figures 2 and 3, Three incinerators (Pinellas County Refuse Recovery, PCRR, 257 ; Hillsborough County Refuse Recovery, HCRR, 263.9 ${ }^{\circ}$ and McKay Bay, $265^{\circ}$ ) lie upwind at nearly the same station angle at distances between 11 and $45 \mathrm{~km}$ (see Figures 2 and 3) Forward trajectories predict arrival of air from the Pinellas County Refuse Recovery (PCRR) incinerator between 15:30 and 16:00. For this reason, the X/Q profile 


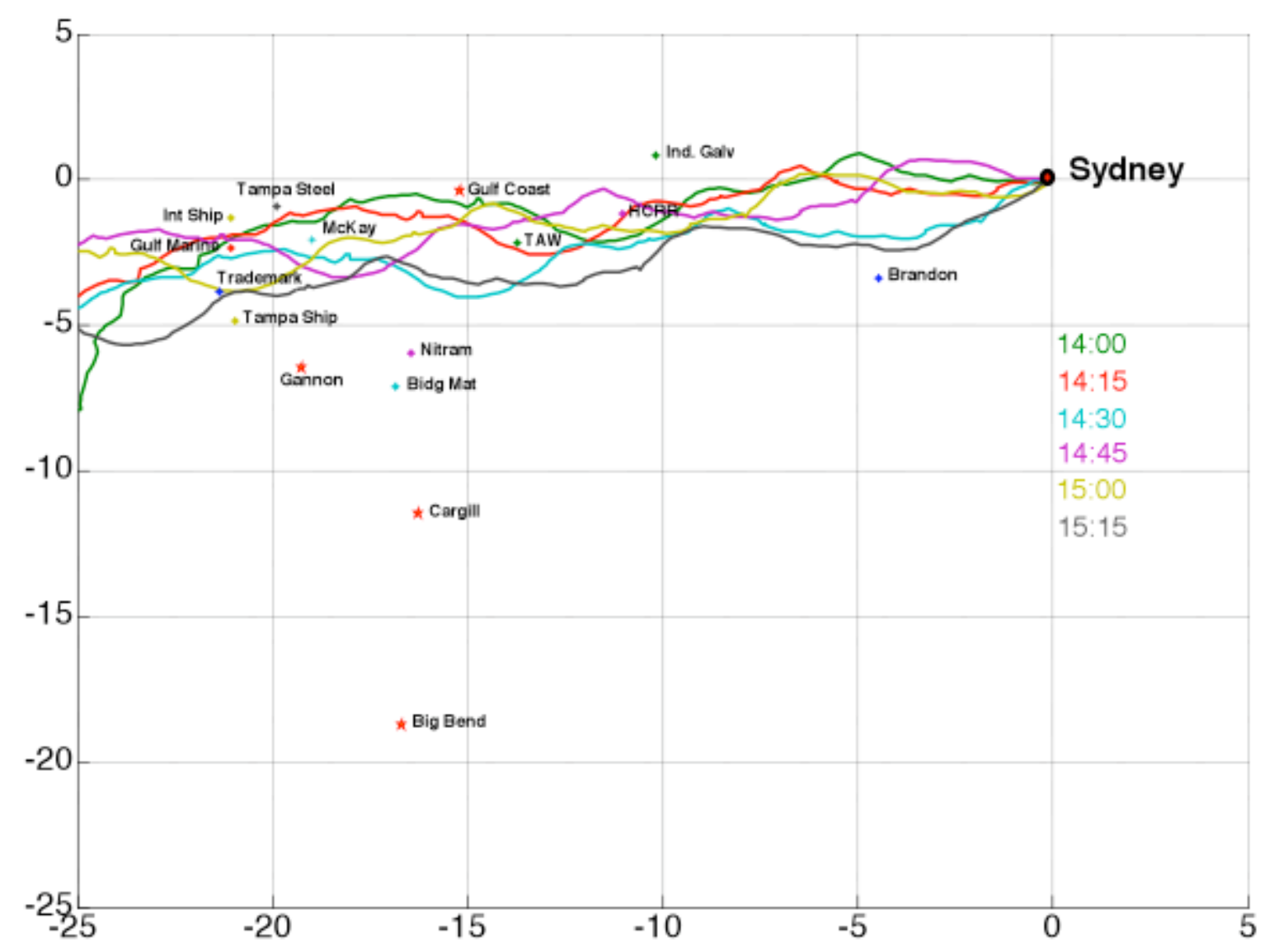

Figure 2. Surface wind back-trajectories calculated for air arriving at Sydney between 14:00 and 15:15 suggest influence from shipyards (Tampa Shipyard and Gulf Marine) between 14:00 and 15:15; Tampa Armature Works at 14:15; and the McKay incinerator 15:00.

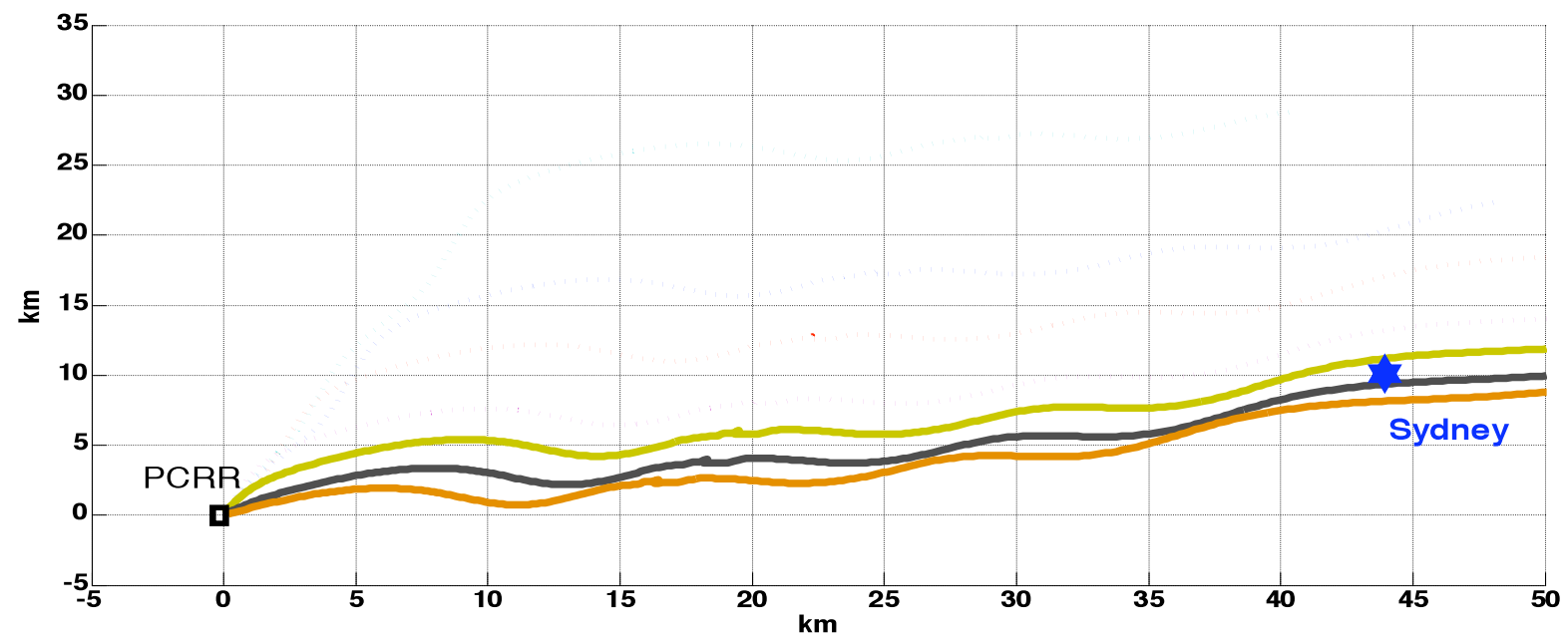

Figure 3. Surface forward wind-trajectories predict air from the PCRR incinerator arriving at Sydney between 15:30 and 16:00. 


\section{Six-Source PDRM X/Q Profiles}

$\mathrm{X} / \mathrm{Q}$ profiles for the original 6 sources are shown in Figures 3. Note that the periods of influence predicted by both the PDRM plume and PDRM least-squares models are identical, as these depend solely on the difference between the wind and station angles. Thus, these differ somewhat in our subsequent PDRM X/Q profiles for Cargill, owing to adjustments to wind angles subsequent to our reanalysis of the back-trajectories, as described above.

As shown in Figure 3, plumes from the various sources in the SE quadrant are predicted to influence air quality at Sydney at various times between 12:00 and 20:30 as surface winds turned from southerly to westerly. The plume from the Manatee OFPP is predicted to arrive at 12:00 and remain strong during the 12:30 sample; as evidenced by an excursion in the ambient $\mathrm{Ni}$ concentration. This was followed by the arrival of plumes from Big Bend plume at 13:00 and Cargill at 13:30, respectively. Plumes from Cargill, Gannon, Bartow, and Gulf Coast seriously overlap between 14:00 and 20:00.
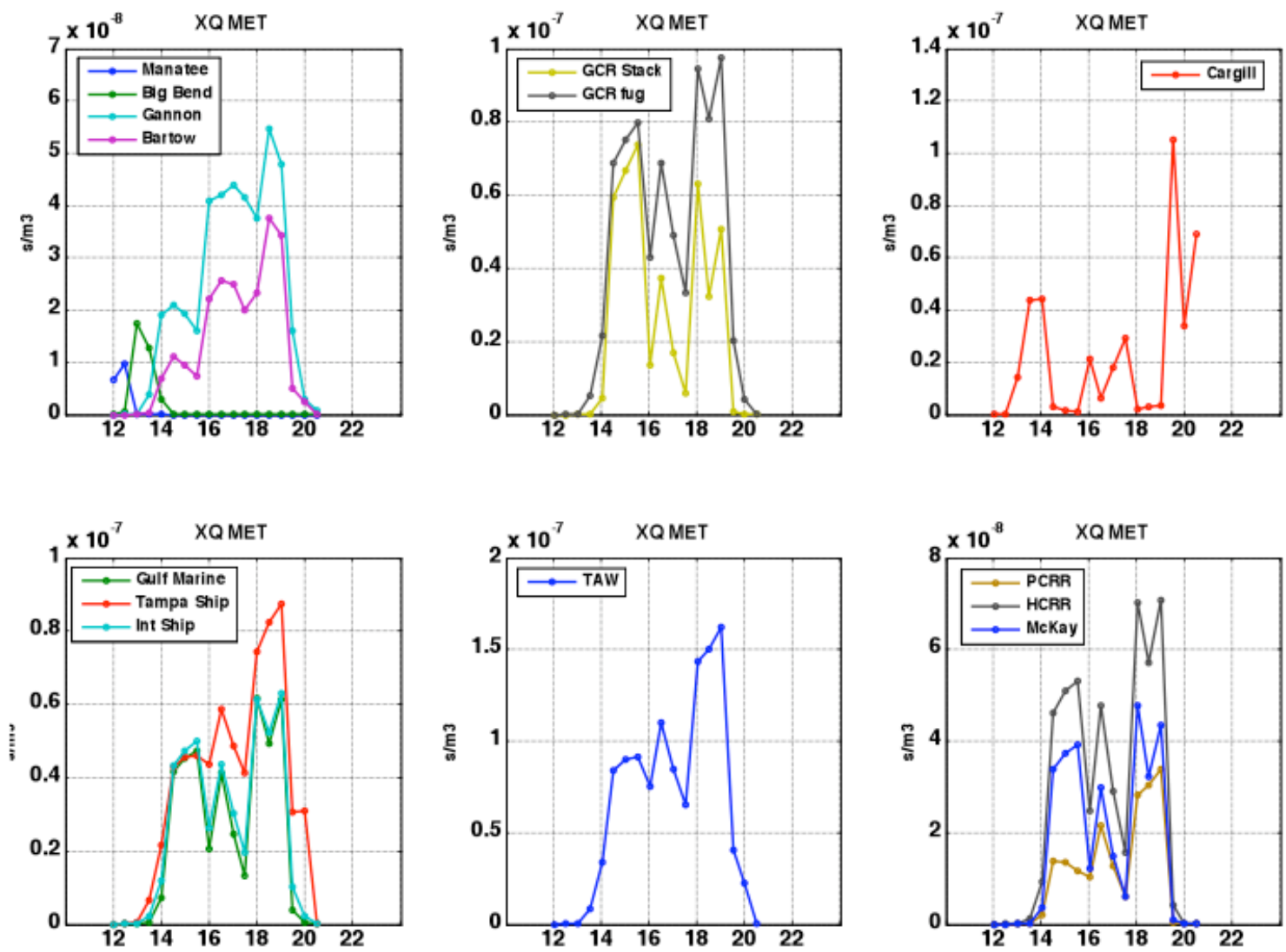

Figure 3. Temporal profiles of X/Qs for each of the 9 candidate sources. All but those for Manatee, Shipyards, incinerators, and the Armature works are those determined by Park et al., 2005. The Manatee profile was recomputed after adjustment of the wind-transport direction as described in the text. Profiles were modified to account for predicted plume arrival times and for the episodic nature of shipyard emissions. PDRM Constraints 
Herein, $\mathrm{SO}_{2}$ emission rates for the four utility power plants were constrained to $+/-5 \%$ of their actual emission rates as determined from continuous emission monitors. For Gulf Coast $\mathrm{SO}_{2}$ emission rate solutions were constrained to within 50\% of its NEI (2002) value; and those for Cargill were constrained to 5\% the value determined Park et al. (2005). In the model of Park et al. (2005), ERs for particle-borne elements were constrained to lie between 0.0001 and $50 \mathrm{~g} / \mathrm{s}$. Herein, we used data from the National Emissions Inventory (NEI, ref) and Toxic Release Inventory (TRI, ref) where available to provide first guesses, upper bounds, and lower bounds. As not all elements are reported in either of these databases, median, lower, and upper bounds were estimated from literature data by taking ratios of elements to one or more of the elements reported by NEI.

For coal-fired power plants, literature data used encompassed i) a composite of CMB profiles developed for eastern US power plants (Sheffield and Gordon) and ii) emission rate measurements made at other facilities (DOE ). For oil-fired power plants, we used a composite of CMB profiles (Sheffield and Gordon) and elemental composition data reported for residual (\#6) fuel oil. For the Gulf Coast recycling plant, and a local incinerator, we used source profiles derived from multivariate statistical modeling (UNMIX) of 30-min SEAS data developed at a site ("Tampa Diary”) more spatially suited for resolution of sources (Pancras et al., 2008).

$$
E R_{X, s}=E R_{r e f(N E I), s}\left(\frac{[X]}{\left[X_{r e f}\right]}\right)_{L i t}
$$

where $\mathrm{ER}_{\mathrm{x}, \mathrm{s}}$ is the emission rate estimate for element $\mathrm{X}$ for source $\mathrm{s}, \mathrm{ER}_{\mathrm{ref}(\mathrm{NEI}), \mathrm{s}}$ is the emission rate for source $s$ reported in the NEI for a reference element $\left(\mathrm{X}_{\mathrm{ref}}\right)$, and $[\mathrm{X}] /\left[\mathrm{X}_{\mathrm{ref}}\right]$ is the concentration ratio of element $\mathrm{X}$ and $\mathrm{X}_{\text {ref }}$ in emissions reported elsewhere for one or more coalor oil-fired power plants.

Elemental emission rates for utility power plants depend on the quality and source of the fuel, the nature and size-dependent efficiency of their control devices, as well as flue- and stack-gas temperatures. Neither fuel composition nor control-device efficiency curves were available, making it difficult to construct reliable estimates of elements not reported in NEI. Consequently elemental emission rates estimated on the basis of different ratios often differed substantially, i.e., by as much as 100-fold. This suggests, that fuel composition and, very likely, control device efficiency functions for the reference and actual plants considered herein are substantially different.

\section{DATA SETS AND RESULTS}

\section{Results of Reanalysis of Tampa Samples}

Results of the prior GFAAZ and the new ICPM analyses are shown in Figure 4, wherein atmospheric concentrations (in $\mathrm{ng} / \mathrm{m}^{3}$ ) of the original 11 elements are plotted versus the time-ofday of initiation of the sample-collection intervals. For both $\mathrm{Cu}$ and Fe, ICPMS results were derived from monitoring of two isotopes to check for data degradation owing to argon ion 
interferences, which can be severe for these elements. Analyses based on ${ }^{63} \mathrm{Cu}$ and ${ }^{65} \mathrm{Cu}$; and ${ }^{56} \mathrm{Fe}$ and ${ }^{57} \mathrm{Fe}$ (not shown) were in excellent agreement, although uncertainties in ${ }^{56} \mathrm{Fe}$ were uniformly smaller than those for ${ }^{57} \mathrm{Fe}$.

In addition to the 11 elements determined previously by GFAAZ (Al, $\mathrm{As}, \mathrm{Cd}, \mathrm{Cr}, \mathrm{Cu}, \mathrm{Fe}, \mathrm{Mn}$, $\mathrm{Ni}, \mathrm{Pb}, \mathrm{Se}$, and $\mathrm{Zn}$ ) 14 new elements (Ag, Ba, Co, La, Sb, V, W, Ca, K, Mg, Na, Sr, Mo, and U) were determined in the samples. Results of these analyses are shown in Figure 5.
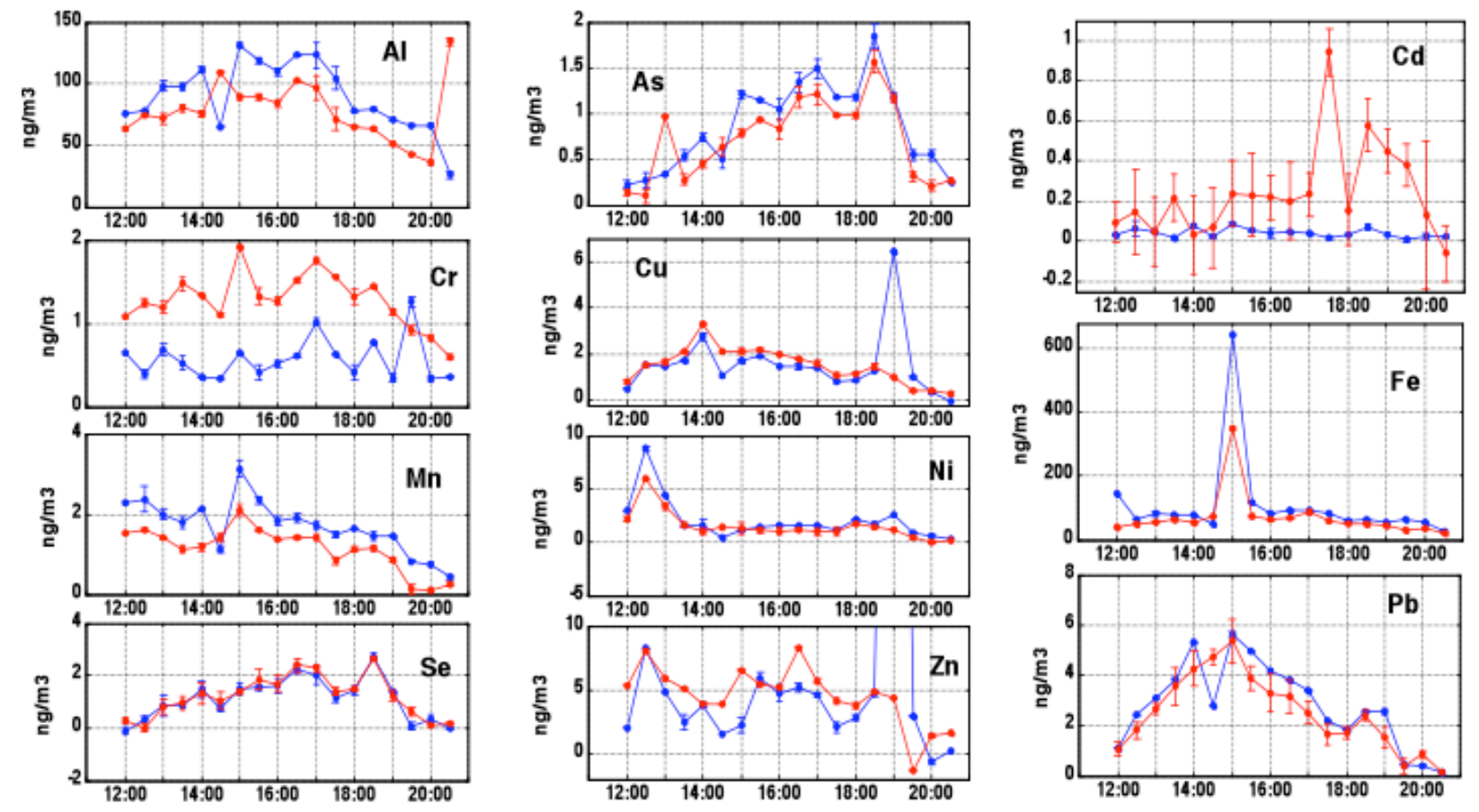

Figure 4. Comparison of atmospheric concentrations of elements determined both by GFAAZ (red) and ICPMS (blue) analyses of samples collected in Tampa, Fl, on May 13, 2002. The dip in Pb, Al, and other elements at 14:30 is attributed to sample loss during heating. ICPMS results were determined after aggressive sample treatment, which led to greater results, especially for refractory elements, $\mathrm{Al}, \mathrm{Cr}$, and $\mathrm{Mn}$. Large differences in $\mathrm{Zn}, \mathrm{Cu}$, and $\mathrm{Cr}$ at 19:00 are attributed to an air leak in the ICPMS sample introduction tubing. Cd was reliably detected by ICPMS but not by GFAAZ. Lastly, the excursion in Al at 20:30 was not detected by ICPMS. 

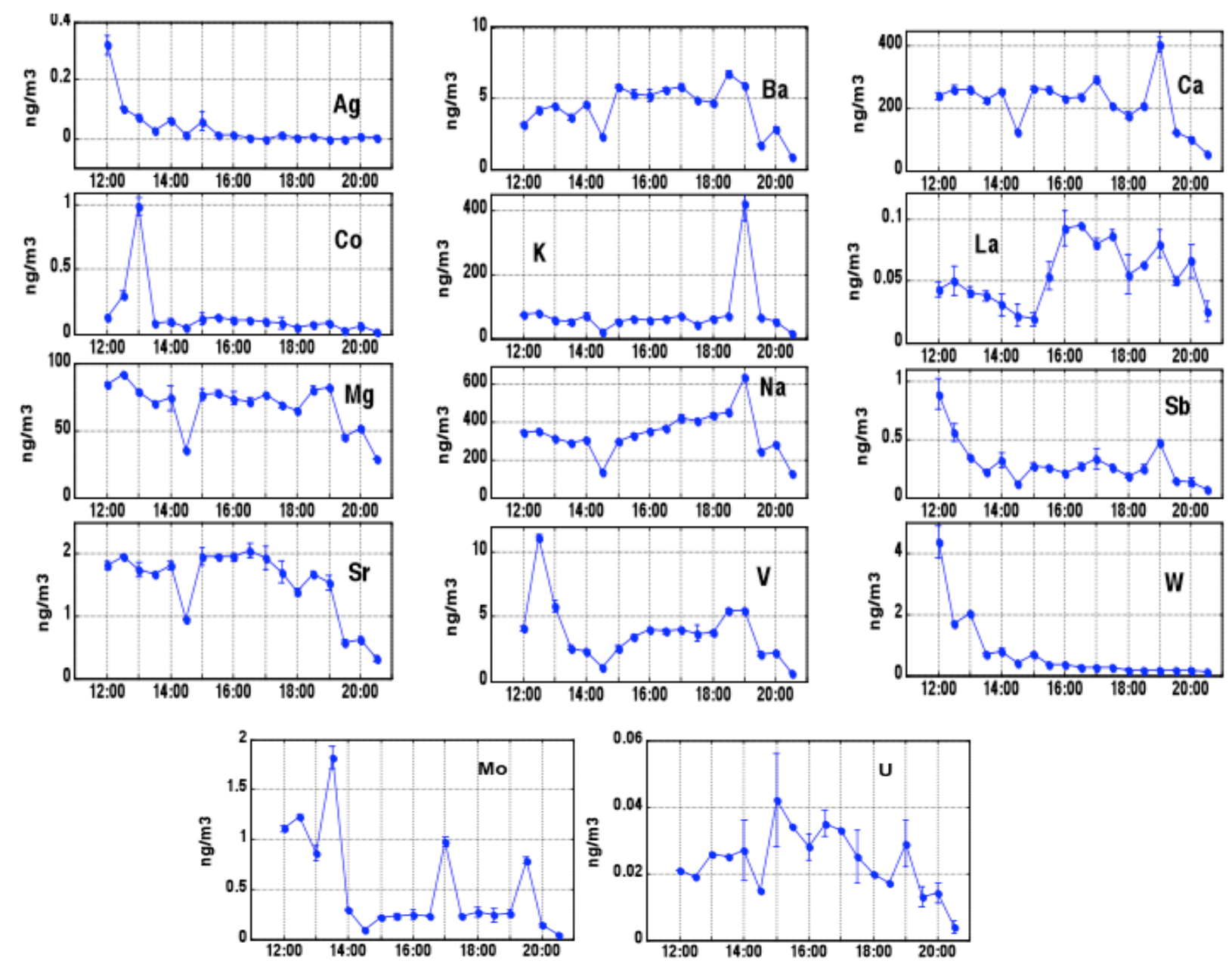

Figure 5. Concentration-versus-time-of-day profiles for 14 additional elements determined by reanalysis of Tampa samples by ICP-MS.

Comparison of GFAAZ and ICPMS results. For most of the elements, ICPMS and prior GFAAZ analysis results agreed to within their uncertainties. However, for $\mathrm{Al}, \mathrm{Fe}, \mathrm{As}$, and $\mathrm{Cr}$, and $\mathrm{Cu}$, ICPMS results were often 1.2 to 2 -fold greater than those determined by GFAAZ. These differences are attributed to the more rigorous sample heating procedures before analysis with the ICPMS, the small statistical sampling of suspended particles (which is always a concern for GFAAS analysis), and the slow leaching of particles stored in the slurry over long periods of time.

In most of the data, excursions observed in the two data sets are well correlated. However, significant discrepancies were observed. The more important of these are as follows.

1. Cd was not well detected by GFAAZ, and was deemed unreliable by Park et al. (2005). Inspection of Figure 2?, reveals that it was detected by GFAAZ in only the samples at 17:30, and 18:30 through 19:30. ICPMS was substantially more sensitive for $\mathrm{Cd}$ and produced results with much smaller uncertainties. $\mathrm{Cd}$ is not volatile or otherwise subject 
to losses upon storage. The large excursion at 17:30 was not detected by ICPMS, and generally, much lower levels were observed.

2. A large excursion in Al appeared at 20:30 in the GFAAZ data set, but not in the ICPMS data set. Al is typically associated with large, difficult to dissolve alumina-silicate dust particles and generally better-measured by ICPMS coupled with our more aggressive sample preparation method. This excursion was ignored by Park et al. (2005), a decision which is now supported by the ICPMS data.

3. A sharp peak in As was detected at 13:00 in the GFAAZ data set, but not in the ICPMS data set. The GFAAZ peak for As is well correlated with a peak in Co as determined by ICPMS, and with the arrival of the plume form the Big Bend power plant, as predicted by the PDRM met module (Park et al., 2005). As discussed above, the Big Bend plume is predicted to be cleanly resolved at this time, except for some overlap with the Ni source, which peaks at 12:30, and which is attributed to the Manatee oil-fired power plant.

Big Bend burns coal and is equipped with both an ESP and a scrubber. The As/Se ratio in this peak is 1.2, i.e., 6-fold greater than 0.18, a mean reported (Sheffield and Gordon, 1986) for fine particles emitted from coal-fired power plants equipped with ESPs.

However, this ratio is highly variable and probably not out of range. Both As and Se are reported to become enriched by the use of a spray tower Flue-Gas Desulfurization system (Ondov et al., 1981), but reported enrichments were substantially larger for Se (15-fold) than for As (2-fold). The Al/Se ratio (120) is consistent with that in fine particles emitted from coal combustion in power plants equipped with ESPs (140; Sheffield and Gordon 1986). Other metals are more highly enriched relative to Se, for example: Fe, 102 versus 9; and Mn, 2.5 versus 0.04; this peak versus Sheffield and Gordon's mean). Given predicted interference from an oil-fired power plant, for which As/Se ratios (mean $=0.4$ ) are greater than those for coal-fired plants, we conclude that the GFAAZ As value cannot be dismissed. Therefore, PMF was run with and without As at 13:00.

4. ICPMS results are generally low for the 14:30 samples. We attribute this to differences in efficiency of sample aspiration between GFAAZ and ICPMS analyses. In this case GFAAZ probably sampled one or more insoluble particles than ICPMS. As noted above, we have observed evidence of settling of larger particles in the ICPMS vials. This created dips most noticeably in $\mathrm{Pb}, \mathrm{Al}$, and $\mathrm{Mn}$, and to a lesser extent in $\mathrm{Cu}, \mathrm{Ni}, \mathrm{Zn}$, and As. Inspection of Figure 5 suggest that these "dips" appear artificial. Therefore, we forced the data at this point to fit the trends of the GFAAZ results.

5. A very large peak in Fe appears at 15:00 along with smaller but distinct peaks in Mn and Cr. Park et al. (2005) attributed the Fe, but not $\mathrm{Mn}$ and $\mathrm{Cr}$, to contamination and removed excess Fe from this peak. The excess Fe (i.e., amount of Fe remaining after subtracting Fe of the preceding period) amounts to $\sim 600 \mathrm{ng} / \mathrm{m}^{3}$ (ICPMS datum) and corresponds to $16 \%$ of the excess PM mass (analogously estimated). This is substantially elevated over the mean crustal abundance of $\mathrm{Fe}(5.6 \%)$; and the $\mathrm{Mn} / \mathrm{Fe}$ ratio $(0.6 \%$ based on the ICPMS data) is consistent with steel (carbon steel contains $<1.65 \% \mathrm{Mn}$ ) and inconsistent with crustal dust (1.9\% Mason). Park et al. (2005) took this to be contamination. Plumes from a sand, rock, and gravel distributer (Conrad) and/or a 
concrete crushing plant (Southern Crushing) would have influenced the sampling site during the 15:00 sampling period, however, Ca does not appear to be elevated at this time, which argues against an influence by the latter source. It seems unlikely that particles enriched in Fe would have been generated by the sand, rock, and gravel facility; therefore, this source was excluded from modeling.

The study-period $\mathrm{Pb}$ maximum also occurs at this time, and is consistent with the prediction of the influence of the Gulf Coast Recycling plant. Gulf coast produces $\mathrm{Pb}$ ingots, some containing $\mathrm{Al}$ or $\mathrm{Sb}$. But it is doubtful that this plant could be responsible for particles with so much Fe.

Both Zn (GFAAZ) and Cd (ICPMS) profiles show elevated levels during the 15:00 hr sampling period. As noted above, three incinerators are located from 11 and $45 \mathrm{~km}$ from Sydney, and are predicted to influence Sydney between 15: and 16:00.

6. In the 19:00 sample, large excursions appear in the ICPMS data for $\mathrm{Zn}$ with $\mathrm{Cu}$, and $\mathrm{Cr}$, but are not present in the GFAAZ data for these elements. These were accompanied by substantial excursions in $\mathrm{K}, \mathrm{Ca}$, and $\mathrm{Na}$, and to a lesser extent $\mathrm{V}, \mathrm{Sr}, \mathrm{Ba}$, and possibly $\mathrm{Sb}$, all elements not determined by GFAAZ. That for $\mathrm{Zn}$ was particularly large but highly imprecise owing to a single large value in one of the three replicate ICPMS scans. This sample had little remaining volume when it was reanalyzed, and we attribute this behavior to the aspiration of one (or possibly a few), probably large, particle(s). This reveals an analytical sampling bias, in that the other samples contained much larger volumes, hence there is a much lower probability of aspirating large particles near the bottom that could be entrained by the sampling probe. For this reason, we used only the average of the two consistent runs in the modeling data sets. However, this peak corresponds to the $\mathrm{SO}_{2}$ maxima which, as discussed below, PDRM attributes mostly to the Gannon coal-fired power plant, with contributions from Cargill and Gulf Coast. Of the elements measured, the major constituents are $\mathrm{Zn}\left(134 \mathrm{ng} / \mathrm{m}^{3}\right), \mathrm{Cu}\left(6.0 \mathrm{ng} / \mathrm{m}^{3}\right), \mathrm{Ni}$ and $\mathrm{Cu}\left(1\right.$ to $\left.\sim 2 \mathrm{ng} / \mathrm{m}^{3}\right)$, and $\mathrm{K}\left(365 \mathrm{ng} / \mathrm{m}^{3}\right), \mathrm{Na}\left(299 \mathrm{ng} / \mathrm{m}^{3}\right), \mathrm{Ca}\left(240 \mathrm{ng} / \mathrm{m}^{3}\right)$, and $\mathrm{Mg}(50$ $\mathrm{ng} / \mathrm{m}^{3}$ ). The $\mathrm{K} / \mathrm{Ca}$ is consistent with soil, i.e., $\sim 1.5$ versus 2.7 for soil (Sheffield et al), and $\mathrm{Na}$ and $\mathrm{Mg}$ are both enriched $\sim 5$-fold over their ratios in soil. This is to be expected for soils contaminated with sea salt as $\mathrm{Na} / \mathrm{Ca}$ and $\mathrm{Mg} / \mathrm{Ca}$ ratios in sea salt are $\sim 20$ and $\sim 3$, respectively. The presence of such a large amount of $\mathrm{Zn}$ might normally be attributed to trash incinerators as these typically emit particles containing up to $40 \% \mathrm{ZnCl}_{2}$ by mass. However, $\mathrm{Zn}$ in this form is quite soluble, and wouldn't have been missed by GFAAZ. The presence of large amounts of Zn along with crustal/sea salt -like composition for $\mathrm{Na}, \mathrm{Ca}, \mathrm{K}$, and $\mathrm{Mg}$, and apparent insoluble nature of the material in this sample is suggestive of fugitive emissions from sandblasting galvanized metal. Abrasive materials made from coal fly-ash are used in several area industries, e.g. Tampa Ship, Tampa Armature, and Industrial Galvanizer. Although X/Q plots for these suggest the possibility of strong influence from the Tampa Armature Works, shipyards, and the HCRR incinerator at 19:00 it is unlikely that HCRR would have been the source of insoluble Zn. But without Fe and other metals, it is doubtful that the Shipyard sources were responsible. If real, it would appear that the Tampa Armature Works would be the best candidate to explain this excursion. The fact that the $\mathrm{Zn}$ level at this time is so much greater than that of $\mathrm{Cu}$ could be the result of burning off the insulation from the wire, 
which is part of the reclamation process. Wire is typically insulated with plastic materials and these contain $\mathrm{Zn}$ plasticizers, which is the source of the large $\mathrm{Zn}$ emissions from municipal incinerators.

PMF Data Sets. Several data sets were prepared specifically to investigate the effects of discrepancies described above and to determine the effect of background correction. Additional PMF model runs were made with and without $\mathrm{SO}_{2}$, and with and without background subtraction. Subsequent data sets were prepared to investigate the influence of inclusion of various species. In each case, 6-, 7-, and 8-factor models were run. The data sets ranged from results determined using only the (core) 11 species originally determined by GFAAZ to data sets encompassing these and all of the new elements determined only by ICPMMS. Owing to differences in concentrations determined by GFAAZ and ICPMS methods, hybrid data sets, wherein weighted averages of the GFAAZ and ICPMS concentrations of one or more were elements replaced the GFAAZ data. The components of each of these data sets are described below. Runs 4, 4A, 4Ai, 4Aii, 4B, 4C, and 4D encompassed variations on the Core data set. Runs 4E, 4F, 4G, and 4I encompassed variations of Core and the additional ICPMS species. Tables of species concentrations in these data sets are shown in Appendix D.

Before computing weighted averages, the GFAAZ data were multiplied by factors ranging from 1.2 to 6 to account for the differences between average concentrations determined by ICPMS and GFAAZ, mentioned above. Uncertainties in the resulting data set were the larger of i) the weighted averages of the individual uncertainties in each pair of concentrations and ii) the difference between the two values, expressed as 1 standard deviation. We argue that the difference between pairs amounts to 2-standard deviations and, therefore, 1 standard deviation values were estimated as $0.65 \mathrm{x}$ the difference. Lastly, ICPMS-derived concentrations at 14:30 were scaled to the GFAAZ trends to account for losses mentioned above in processing the 14:30 for ICPMS analysis.

Table 1. Composition of PMF Data sets

\begin{tabular}{|c|c|c|c|c|c|c|c|c|c|c|}
\hline Run & $\begin{array}{l}\text { Background } \\
\text { corrected }\end{array}$ & $\mathrm{SO}_{2}$ & Zn weighted & $\begin{array}{l}\text { Extra ICPMS } \\
\text { elements }\end{array}$ & $\begin{array}{c}\text { Cd } \\
\text { GFAAZ }\end{array}$ & $\begin{array}{c}\text { Cd } \\
\text { ICPMS }\end{array}$ & $\begin{array}{l}\text { Zn uncertainties } \\
\text { increased }\end{array}$ & $\begin{array}{l}\text { Cu uncertainties } \\
\text { increased }\end{array}$ & $\begin{array}{c}\text { Eliminate } \\
\mathrm{dCr}, \mathrm{K}, \\
\mathrm{Mg}, \mathrm{Na}\end{array}$ & $\begin{array}{c}\text { Eliminated } \\
\text { Al, Mn, Ba, } \\
\text { La, Ca, Sr }\end{array}$ \\
\hline 4 & 1 & 1 & 0 & 0 & 1 & 0 & 0 & 0 & 0 & 0 \\
\hline $4 \mathrm{~A}$ & 1 & 1 & 0 & 0 & 0 & 0 & 0 & 0 & 0 & 0 \\
\hline $4 \mathrm{~A} i$ & 0 & 1 & 0 & 0 & 0 & 0 & 0 & 0 & 0 & 0 \\
\hline $4 \mathrm{~A}$ ii & 0 & 0 & 0 & 0 & 0 & 0 & 0 & 0 & 0 & 0 \\
\hline $4 \mathrm{~B}$ & 1 & 1 & 1 & 0 & 0 & 0 & 0 & 0 & 0 & 0 \\
\hline $4 C$ & 1 & 1 & 1 & 0 & 0 & 0 & 0 & 1 & 0 & 0 \\
\hline $4 \mathrm{D}$ & 1 & 1 & 1 & 0 & 0 & 1 & 1 & 1 & 0 & 0 \\
\hline $4 \mathrm{E}$ & 1 & 1 & 1 & 1 & 0 & 1 & 0 & 0 & 0 & 0 \\
\hline $4 \mathrm{~F}$ & 1 & 0 & 1 & 0 & 0 & 1 & 0 & 0 & 0 & 0 \\
\hline $4 \mathrm{G}$ & 1 & 0 & 1 & 1 & 0 & 1 & 0 & 0 & 0 & 0 \\
\hline $4 \mathrm{H}$ & 1 & 0 & 0 & 0 & 0 & 0 & 0 & 0 & 0 & 0 \\
\hline 41 & 0 & 0 & 1 & 1 & 0 & 1 & 0 & 0 & 0 & 0 \\
\hline $4 \mathrm{~J}$ & 1 & 1 & 1 & 1 & 0 & 1 & 1 & 1 & 0 & 0 \\
\hline $4 K$ & 0 & 1 & 1 & 1 & 0 & 1 & 1 & 1 & 0 & 0 \\
\hline $4 \mathrm{~L}$ & 0 & 1 & 1 & 1 & 0 & 1 & 1 & 1 & 1 & 0 \\
\hline $4 M$ & 0 & 1 & 1 & 1 & 0 & 1 & 1 & 1 & 1 & 1 \\
\hline
\end{tabular}




\section{PMF Results}

PM mass versus time-of-day profiles for each model run are plotted in Figures 6, 7, and 8. The results are displayed in separate subplots, wherein like-factors (LF) from each set of n-factor runs on the same data set are grouped. The factors are identified on the basis of the X/Q profiles determined by PDRM and/or compositional features of the factors in correlation with the ambient species data. Graphs displaying the profiles of different factor identities are arranged vertically, and results for different data sets are arranged in columns from left to right. Where possible, the strengths of correlation between the PMF factor- and PDRM-X/Q-profiles are indicated by $\mathrm{R}^{2}$ values for the best of the $n$-factor runs. These are shown on each subplot. Herein, confidence levels for various values of $\mathrm{R}^{2}$ range from $<70 \%\left(\mathrm{R}^{2}=0.50\right)$ to $96 \%\left(\mathrm{R}^{2}=0.95\right)$. The PMF fitting parameter, $\mathrm{Q} / \mathrm{p}$, for all models was $\leq 1.3$. A value $<2$ is considered to be indicative of a well-fit model. The lowest value of $\mathrm{Q} / \mathrm{p}$ is invariably achieved for the model fitting the greatest number of factors, however, these differences are insignificant relative to the uncertainties in the models and, here, the best model is chosen by the significance of the correlations with PDRM X/Qs and other measures of physical significance.

PMF results for Core data sets. Using only the core data sets (maximum of 11 species), up to 7 (like-) factors could be resolved by PMF. In each case, residual or unidentifiable mixed factors were also resolved, and these are displayed in the last two columns in Figures 6 -8. Five factors were common to all PMF-Core models and are identified as: LF1) Manatee, recognizable by virtue of the $\mathrm{Ni}$ (and in later models $\mathrm{V}$ ) excursion at 12:30; LF2) a Cu factor peaking at 14:00; LF3) Fe factor peaking at 15:00; LF4) a Gannon factor; LF5) a mixed Gannon + Bartow factor; LF6 which generally correlated best with Gulf Coast, and in some cases LF7 often correlating best with the sum of theGulf Coast and Cargill X/Q profiles. Correlation between PMF Gannon and the PDRM Gannon X/Q profiles were most often significant at or above the $90 \%$ confidence level. A separate factor for Bartow could not be resolved in any of the PMF-Core runs. Instead LF-5 was consistently better correlated with the sum of the PDRM-X/Q profiles for Gannon and Bartow, and these correlations were significant at confidence levels ranging from $\sim 70 \%$ to $>92 \%$. Correlations between the PDRM-Manatee LFs and Manatee-PDRM-X/Qs were generally low (confidence levels $\sim 60 \%$ ) owing to the 30 minute difference between peak X/Q and the maximum in the $\mathrm{Ni}$ concentration. However, this source was well resolved from the others.

Effect of GFAAZ Cd removal. With GFAAZ Cd (PMF 4) in the Core data set, Cd appeared in a separate factor (LF7) and only the first 5 like-factors could be resolved (see first two subplot rows in Figure 6). With GFAAZ Cd removed (PMF 4A), a factor identified as Gulf Coast was resolved in the 7-factor model and was correlated with a confidence level $>75 \%$. The Gannon and Gannon/Bartow factor correlations with PDRM-X/Q profiles improved slightly. Thereafter, models including Cd in the data set employed only ICPMS Cd.

Influence of $\mathbf{Z n}$ and $\mathbf{C u}$ discrepancies. The effect of replacing GFAA $\mathrm{Zn}$ with the weighted average of GFAA and ICMPS $\mathrm{Zn}$ is seen by comparing PMF 4A and 4B (subplot rows 2 and 3, Figure 6). This improved the level of confidence in the correlation for the Gannon/Bartow Factor from $\sim 69 \%$ (PMF 4A) to $80 \%$ (PMF4B). However, the confidence level of correlation for the Gulf Coast factor decreased by $5 \%$ and the stability of the Manatee and 14:00 $\mathrm{Cu}$ factor decreased among 
the $3 \mathrm{n}$-factor runs. Nonetheless, amounts in residual factors (LF7 and LF8) were substantially reduced, and all of this considered, we chose to use the weighted-Zn data in all subsequent model runs.

In PMF 4C, the uncertainty in the concentration of $\mathrm{Cu}$ at 19:00 was increased to ?? and the weighted $\mathrm{Zn}$ data were again used in this set of $\mathrm{n}$-factor models. This resulted in a slight improvement in the correlation significances of the Gannon/Bartow factor (80 to $84 \%$ ), but further reduced the stability of the Manatee factor and increased the concentrations in LF-7, which we interpret as a residual factor. In PMF 4D, the same dataset (4C) was again used, except that the uncertainty in $\mathrm{Zn}$ at 19:00 was also inflated. This resulted improved correlation confidence limit for the Gulf Coast factor by $6 \%$ while only slightly degrading that for the Gannon/Bartow factor by $2 \%$. Those for the Manatee and Gannon LFs remained unchanged, but the size of the residual factors were the lowest of PMF runs $4 \mathrm{~A}, 4 \mathrm{~B}, 4 \mathrm{C}$, and 4D. Lastly the sum of the correlation confidence levels (best for each n-factor model) was also the best (albeit, marginally) for run 4D (i.e., 321 for 4D; versus 316, 313, 306, and 228 for 4C, 4B, 4A, and 4). Thus, subsequent models were run with the increased $\mathrm{Zn}$ and $\mathrm{Cu}$ uncertainties.
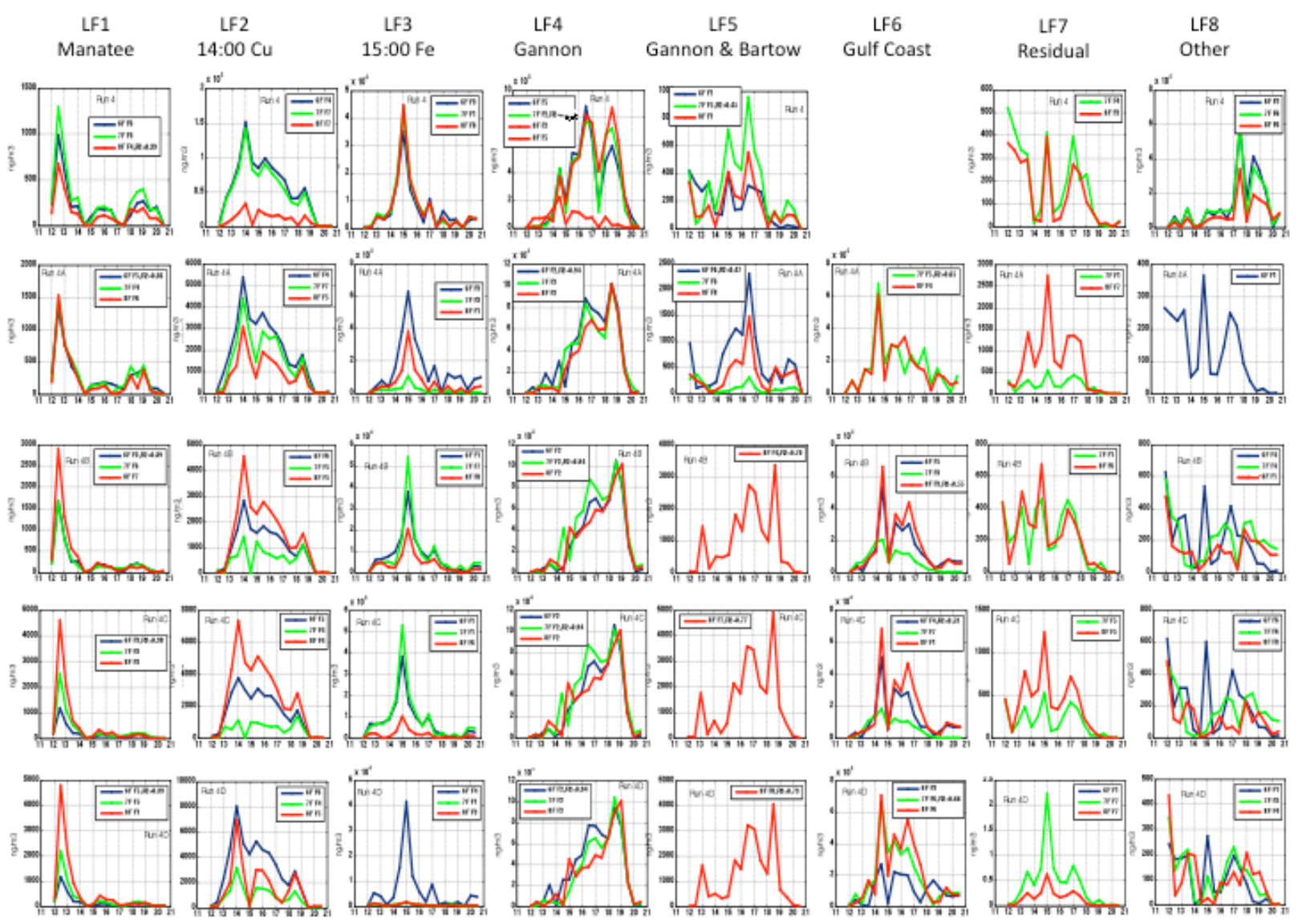

Figure 6. Results of PMF-Core species runs 4, 4A, 4B, and 4C. The core species data set is better explained with GFAAZ Cd removed (PMF 4A). 
Effect of background correction and removal of $\mathrm{SO}_{2}$. While PDRM should be background corrected, background corrected data are generally not used in PMF. The effect of background correction on Core dataset (4A) is seen by comparing PMF runs 4A and 4Ai shown in Figure 7. As indicated in Table 1, both sets of models were run with $\mathrm{SO}_{2}$. With background subtraction undone, the confidence levels for Manatee (70 versus 64\%) and Gannon/Bartow (87 versus 69\%) factor correlations improve substantially, while those for Gannon and Gulf Coast remain the same (95 and $77 \%$, respectively). The strengths of LF7 and LF8 were substantially reduced to residual levels, although the latter became more well correlated Gulf Coast. Of these two, Run 4Ai appears to be the better model set despite the degradation in the confidence level of the Gulf-Coast factor (LF6).

Although it is an accurately determined species, $\mathrm{SO}_{2}$ is not a unique component of any of the major power plant sources. Removal of $\mathrm{SO}_{2}$ from the background-uncorrected Core data set of Run 4Ai (to make 4Aii) resulted in reduced correlation confidence limits for Manatee (66 versus 70\%), Gannon (91 versus $95 \%$ ), and Gannon/Bartow ( 81 versus $87 \%$ ), but substantially improved the factor attributed to Gulf coast ( 77 versus 58\%). However, LFs 7 and 8 became much stronger, i.e., comparable to loadings associated with the other, better indentified, factors. The n-factor models of LF7 became highly coherent, suggesting that this may reflect a real source or sources. But given the times corresponding to their peaks, LF7 is most likely a composite of LF 2 (15:00 Fe) and other factors, hence we deem 4Ai to be the better model. Thus, we conclude that better results are obtained using non-background corrected data and with $\mathrm{SO}_{2}$ included in the data set.

Nonetheless, when $\mathrm{SO}_{2}$ was from run 4A (background corrected dataset), a strong factor consistent with the arrival of Big Bend's plume at 12:30 was resolved in the 7-factor model (See Run $4 \mathrm{H}, 4^{\text {th }}$ row of subplots in Figure 7). LF7 in 4H, again, appears to be a mixture of LF3 (15:00 Fe) and other factors. It is equally well correlated with the X/Q profiles of Cargill+Gulf Coast and Gulf Coast, and is comparable in strength to the other major factors. Such a strong residual factor is as likely as not, to be an artifact of the noise in the data. Given that removal of $\mathrm{SO}_{2}$ in $4 \mathrm{H}$ the correlation confidence level decreases for three of the first 4 LFs (See Figure 7), we concluded that this comparison also supports maintaining $\mathrm{SO}_{2}$ in the datasets.

PMF results for expanded data sets. As indicated in Table 1, expanded data sets include the complete data set (Runs $4 \mathrm{~K}$ and $4 \mathrm{~J}$ ), encompassing the core elements plus all new elements determined by ICPMS; and three additional data subsets wherein sets of elements, which we believed provided the lowest discriminating power, were cumulatively and successively removed. Herein, discriminating power was taken to be the ratio (herein abbreviated as DPRs) of the maximum and minimum values of the concentrations of elements during the study period. Other metrics of discriminating power were considered, but despite its simplicity, this appeared to be the most useful. On the basis of DPRs, two subsets were identified for removal from the complete data set. These were $\mathrm{Cr}, \mathrm{K}, \mathrm{Mg}$, and $\mathrm{Na}$ (DPR <5); and $\mathrm{Cr}, \mathrm{K}, \mathrm{Mg}$, and $\mathrm{Na}$, and $\mathrm{Al}, \mathrm{Mn}, \mathrm{Ba}, \mathrm{La}, \mathrm{Ca}$, and $\mathrm{Sr}$ $(\mathrm{DPR}<7.5)$. These correspond to PMF runs $4 \mathrm{~L}$ and $4 \mathrm{M}$, respectively. Note that $\mathrm{Na}, \mathrm{Mg}, \mathrm{Ba}$, and $\mathrm{Sr}$ have similar temporal profiles (Figure 5). In PMF run 4M Ag, W, and $\mathrm{Sb}$ were also removed from the list of elements used in PMF run 4M. The results are plotted in Figures 8 and 9.

As shown in Figure 8, the Manatee (LF1) and Gannon (LF4) factors are readily identified in results for all expanded data sets. With background subtraction (Run 4J), the correlation for LF6 (Gulf Coast) is dramatically reduced from 0.73 (Run $4 \mathrm{~K}$ for which background was subtracted) to 0.15 , 
although that for the Gannon/Bartow factor (LF5) is substantially improved (0.77 versus 0.65 ). Of the three runs with background-subtracted expanded data sets $(4 \mathrm{~K}, 4 \mathrm{~L}$, and $4 \mathrm{M})$, comparison of results for runs $4 \mathrm{~K}$ and $4 \mathrm{~J}$ shows that correlations for Gannon/Bartow (LF5) and Gulf Coast (LF6) factors are substantially degraded by removal of the first group of elements (compare $4 \mathrm{~K}$ and $4 \mathrm{~J}$ ), i.e., contrary to our expectations. Removing all elements with $\mathrm{DPR}<7.5$, however, gave results very similar to those for the complete data set (4K), but with substantial changes to the shape of LF5. In results for runs $4 \mathrm{~K}$ and $4 \mathrm{M}, \mathrm{LF} 2$ (the $\mathrm{Cu}$ Factor) contained (more or less) the same set of three peaks as the core-only models (e.g., 4D), but their relative heights became more similar and substantially larger (especially in 4M) than in 4D. The Fe factor (LF3), however, became less significant, but more broad, seemingly encompassing both the $\mathrm{Fe}$ and $\mathrm{Cu}$ excursions in the time series data.

All of the model results for the expanded data set included a separate factor with the shape of the concentration-versus-time profiles of $\mathrm{Sb}, \mathrm{W}$, and $\mathrm{Ag}$. We could find no logical source for these elements. Reanalysis of the ICPMS data indicated that their determinations were compromised by poor rinse efficiency. Removal of $\mathrm{Sb}, \mathrm{W}$, and $\mathrm{Ag}$ (run $4 \mathrm{~N}$ ) improves the correlation with the Manatee and Gannon (slightly) factors, but LF6 becomes severely mixed and LF2 (Cu) is shifted away from 14:00 perhaps more like the Fe Factor. 

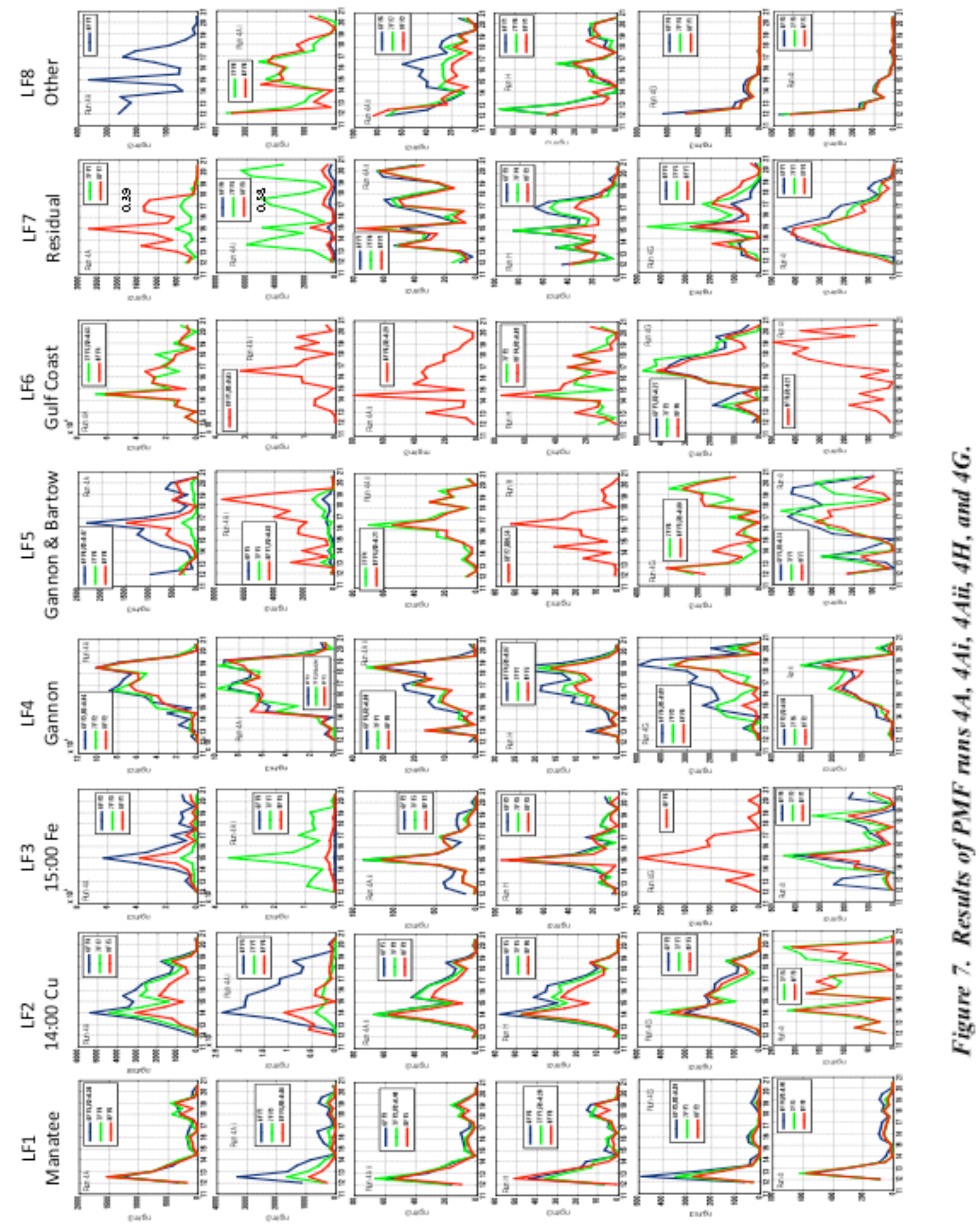

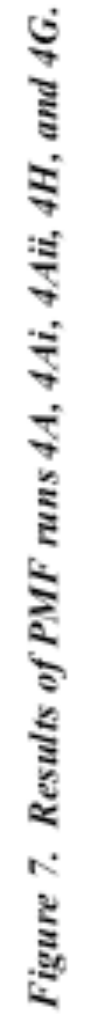



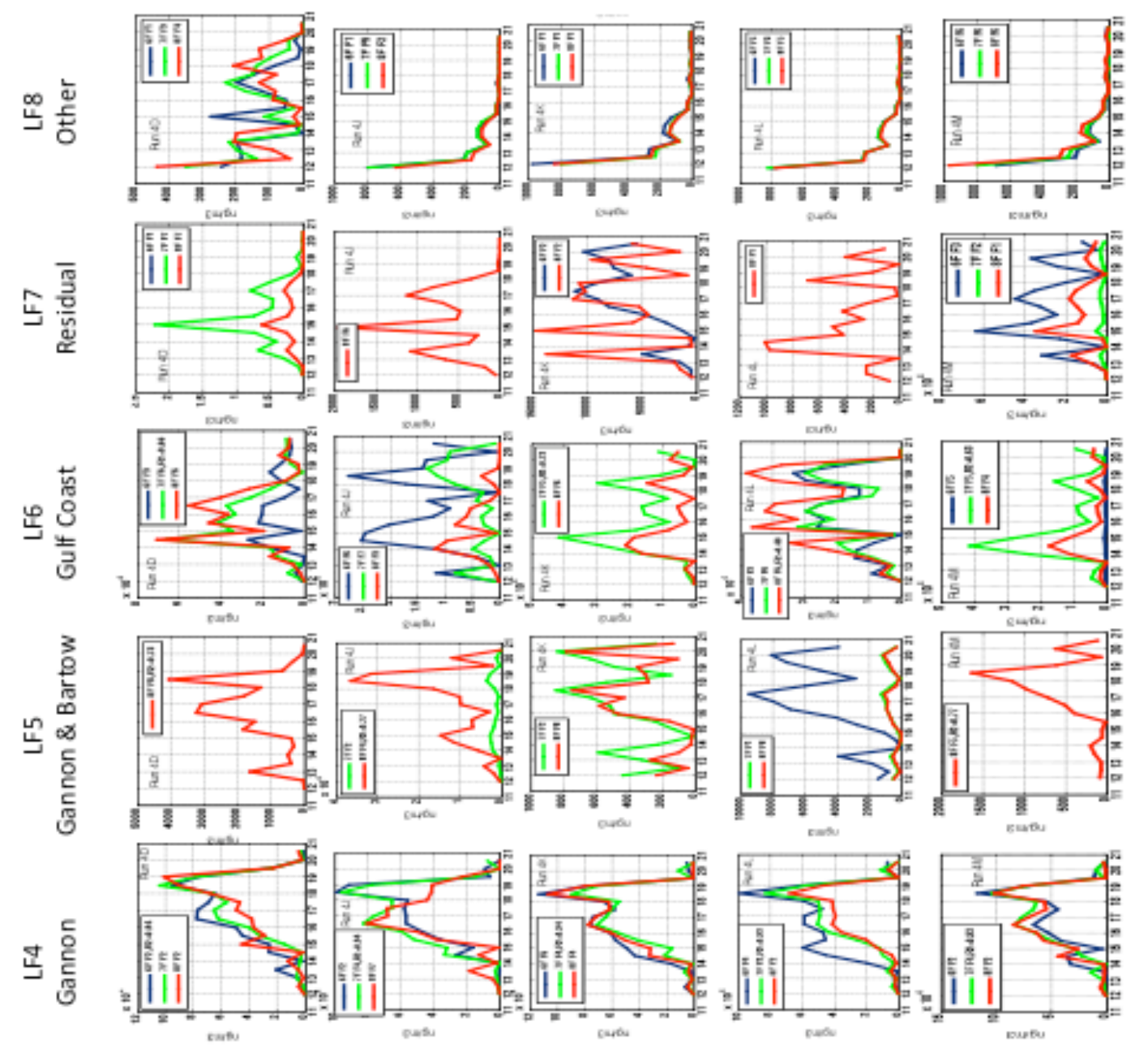

ऐa
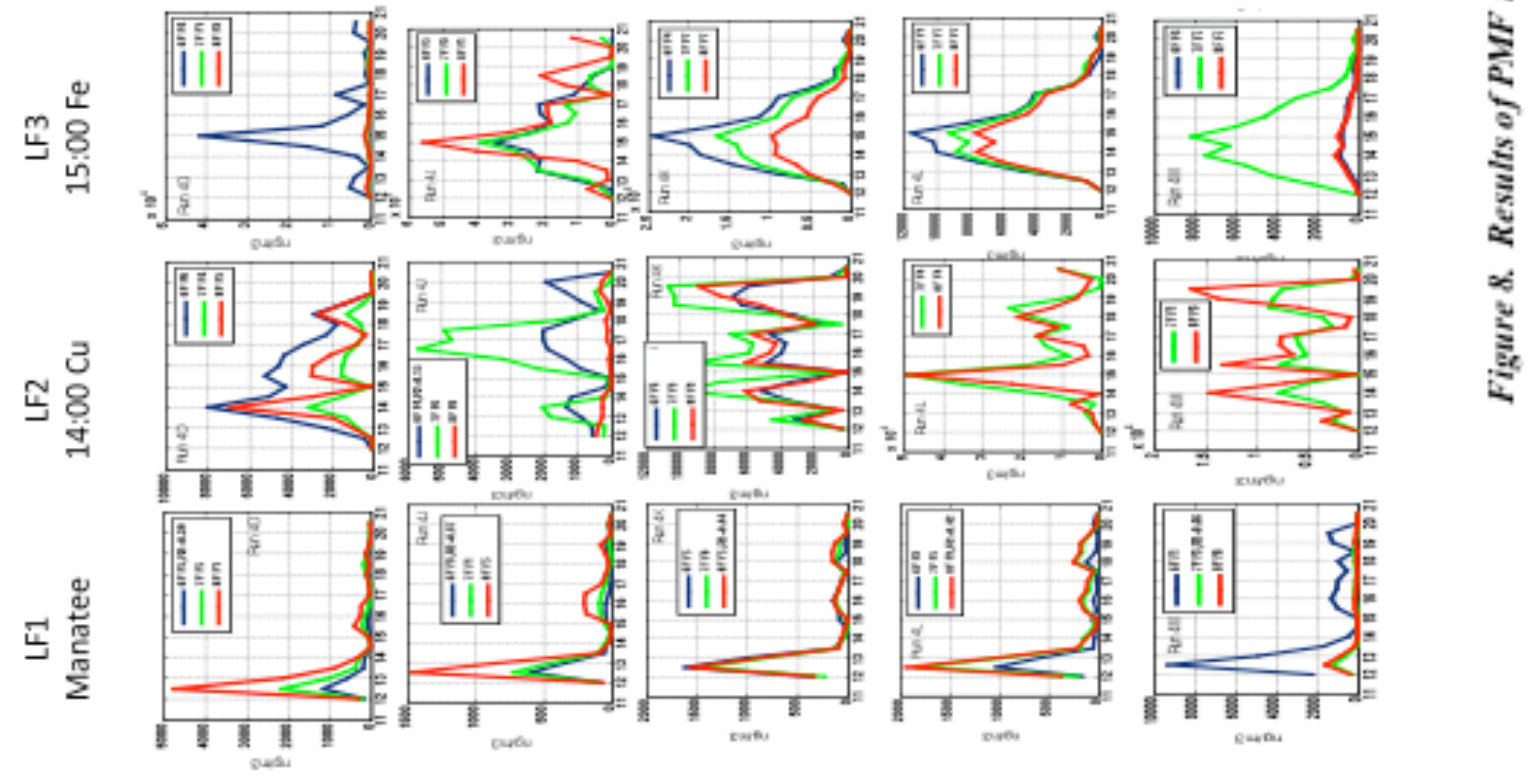

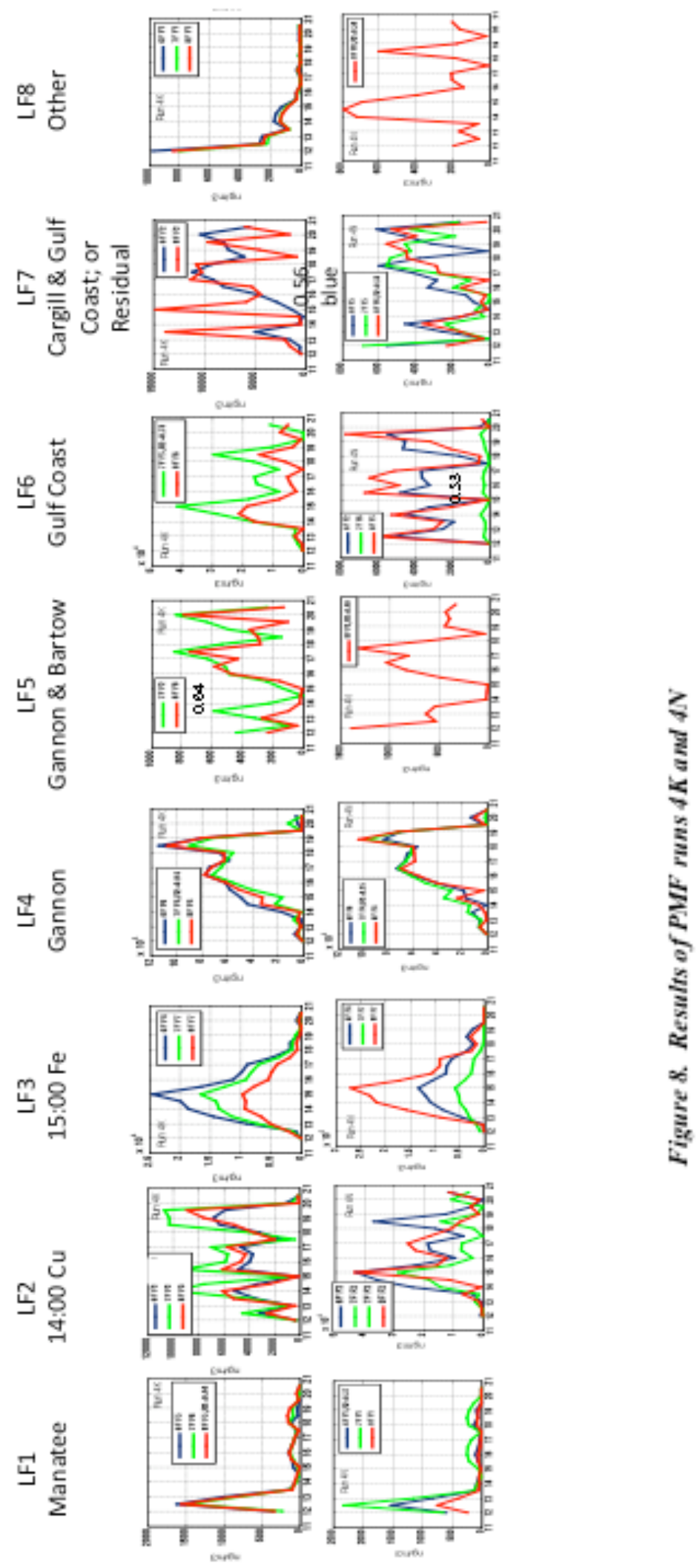

娄 


\section{PDRM Results}

PDRMs were run on several sets of data, each encompassing all 23 elements and $\mathrm{SO}_{2}$. Results of two 6-source model runs are described here. In PDRM Run 3, solutions for emission rates for the elements were constrained to lie between 0.0001 and $50 \mathrm{~g} / \mathrm{s}$, as done by Park et al. (2005). In Run 7J, lower and upper bounds for elemental solutions were $\pm 10 \%$ of the their NEI emission rate values where available and upper and lower bounds determined from CMB source profiles. Exceptions were as follows. To fit the observed data, upper and lower bounds for $\mathrm{As}$ and $\mathrm{Sb}$ had to be expanded to those predicted for Gannon, Bartow, and Gulf Coast based on CMB source profiles. NEI values for each of the sources are listed in APPENDIX D along with first guesses $\left(\mathrm{X}_{\mathrm{o}} \mathrm{s}\right)$, and upper- and lower- bounds used in the models.

Predicted emission rates for both model runs are listed in APPENDIX E. Ratios of predicted to NEI emission rates are listed in Table 2. Predicted and measured ambient concentrations are shown in Figure 10.

Table 2. Ratios of PDRM Predicted Emission Rates to NEI (2002) Values

\begin{tabular}{|c|c|c|c|c|c|c|c|c|c|c|c|c|c|}
\hline \multicolumn{4}{|c|}{ Gannon } & \multicolumn{5}{|c|}{ Manatee } & \multicolumn{5}{|c|}{ Big Bend } \\
\hline Run 7J & TRI & $\begin{array}{c}\text { Park et } \\
\text { al. }\end{array}$ & $\begin{array}{l}\text { (Park } \\
\text { et al) }\end{array}$ & Run 3 & Run 7J & TRI & $\begin{array}{c}\text { Park et } \\
\text { al. }\end{array}$ & $\begin{array}{l}\text { (Park } \\
\text { et al) }\end{array}$ & Run 3 & Run 7 & TRI & $\begin{array}{c}\text { Park et } \\
\text { al. }\end{array}$ & $\begin{array}{l}\text { (Park } \\
\text { et al) }\end{array}$ \\
\hline 2730 & 958 & 2064 & 1998 & 4.2 & 1.6 & & 0.8 & 0.1 & 409 & 518 & & 984 & 933 \\
\hline 0.9 & & & & 2.8 & 2.5 & & & & 0.1 & 0.2 & & & \\
\hline 1.2 & 0.9 & 3.0 & 2.5 & 30.5 & 22.4 & & 32.9 & 44.5 & 2.7 & 1.7 & & 2.4 & 2.5 \\
\hline 1.1 & 0.7 & 0.2 & 0.6 & 16.4 & 8.0 & & 9.5 & 11.1 & & & & & \\
\hline 1.1 & 0.9 & 0.2 & 1.0 & 1.7 & 1.7 & 0.6 & 1.2 & 1.3 & 3.0 & 1.1 & 12.7 & 1.1 & 2.0 \\
\hline 0.9 & 1.4 & 0.5 & 2.1 & 26.7 & 2.9 & & 15.2 & 18.3 & 3.7 & 3.7 & & 2.9 & 2.4 \\
\hline 1.1 & & 0.7 & 0.7 & 6.7 & 6.1 & & 9.7 & 12.0 & 0.5 & 0.6 & & 0.04 & 0.04 \\
\hline 0.9 & 0.8 & & & 0.8 & 0.9 & & & & 4.9 & 3.3 & & & \\
\hline 1.6 & & & & 2.9 & 1.1 & & & & 10.5 & 3.1 & & & \\
\hline
\end{tabular}

\section{Gulf Coast Bartow}

\begin{tabular}{ccccccccccc}
\hline & Run 3 & Run 7J & TRI & $\begin{array}{c}\text { Park et } \\
\text { al. }\end{array}$ & $\begin{array}{c}\text { (Park } \\
\text { et al) }\end{array}$ & Run 3 & Run 7J & TRI & $\begin{array}{c}\text { Park et } \\
\text { al. }\end{array}$ & $\begin{array}{c}\text { (Park } \\
\text { et al) }\end{array}$ \\
& & & & & & & & & & \\
As & 0.7 & 2.5 & 1.8 & 19.9 & $\mathbf{0 . 1 7 1}$ & $\mathbf{0 . 2}$ & $\mathbf{2 . 3}$ & $\mathbf{1 3 . 7}$ & $\mathbf{1 3 . 7}$ \\
Cd & 0.0 & 0.2 & & & & & $\mathbf{0 . 8}$ & & & \\
Cr & 1.3 & 2.8 & 88.4 & 1121.3 & & $\mathbf{9 . 4}$ & 6.4 & $\mathbf{1 2 . 7}$ & $\mathbf{1 0 . 3}$ \\
$\mathbf{M n}$ & 0.6 & 1.1 & 1.2 & 14.2 & & $\mathbf{1 . 1}$ & & $\mathbf{0 . 2}$ & $\mathbf{1 . 0}$ \\
$\mathbf{N i}$ & 0.5 & 1.1 & 0.9 & 6.1 & 0.017 & $\mathbf{0 . 4}$ & & $\mathbf{0 . 0}$ & 0.05 \\
$\mathbf{P b}$ & 0.1 & 0.4 & 0.1 & 1.0 & & $\mathbf{0 . 6}$ & & $\mathbf{0 . 2}$ & 0.7 \\
$\mathbf{S e}$ & 1.7 & 1.3 & 4.4 & 13.1 & 8.353 & $\mathbf{1 . 1}$ & & $\mathbf{2 1 . 7}$ & 21.7 \\
$\mathbf{C o}$ & 3476.2 & 0 & & & & 0.053 & $\mathbf{0 . 9}$ & & & \\
$\mathbf{S b}$ & 0.1 & 0.5 & & & & & $\mathbf{0 . 8}$ & & &
\end{tabular}

Predicted and measured concentrations for Run $7 \mathrm{~J}$ were in excellent agreement for $\mathrm{SO}_{2}, \mathrm{As}, \mathrm{V}, \mathrm{Ni}$, $\mathrm{Na}, \mathrm{Ba}$, and $\mathrm{K}$. Agreement was good for $\mathrm{Fe}, \mathrm{Cu}, \mathrm{Mg}, \mathrm{Co}$, and $\mathrm{La}$. Excursions of $\mathrm{Cu}$ at 14:00 and $\mathrm{Fe}$ at 15:00 were again, not fit well with the 6 sources. The excellent fit for As could only be achieved 

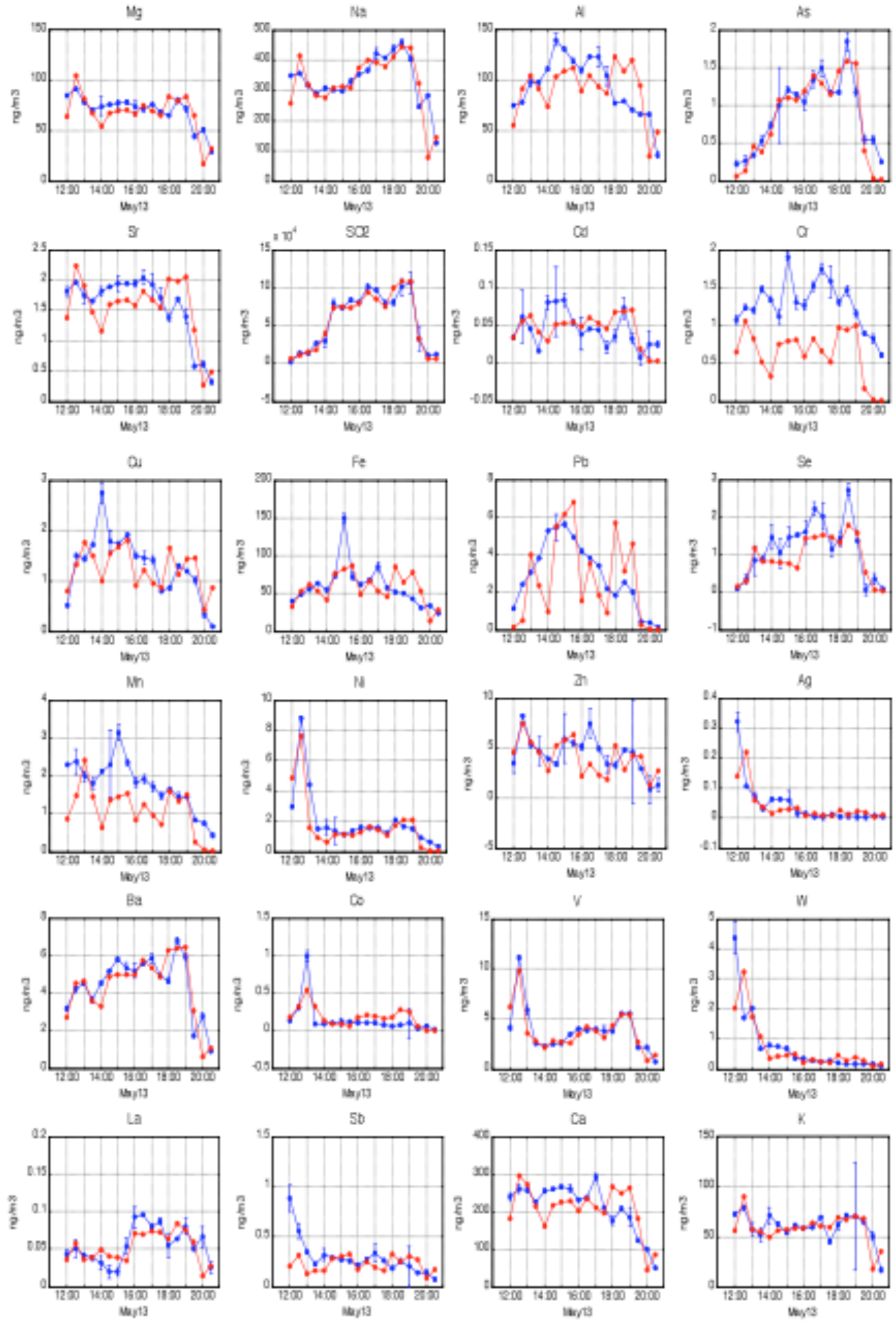

Figure 10. Predicted (red) and observed (blue) ambient concentrations, PDRM Run $7 J$. 
By reducing the upper bound estimates (i.e., by 50\%). As indicated in Table 2, predicted emission rates required to fit the ambient data severely exceed the NEI values for Gannon and Big Bend, while

those for Manatee and Gulf Coast are exceeded only by factors of 1.6 and 2.5 respectively. Two-fold differences are within differences expected from variation in coal composition. But 500-fold differences are probably not, although they do appear to be in the range of published values.

\section{REFERENCES AND BIBLIOGRAPHY}

Bergerioux, C., Zikovsky, L., (1978), Determination of 18 Trace Elements in Petroleum and its Derivatives By Neutron Activation with a small Nuclear Reactor, Journal of Radioanalytical Chemistry, 46:277-284.

Bettinelli, M., Spezia, S., Baroni, U., Bizzarri, G., (1995), Determination of Trace Elements in Fuel Oils by Inductively Coupled Plasma Mass Spectrometry after Acid Mineralization of the Sample in a Microwave Oven, Journal of Analytical Atomic Spectrometry, 10:555560.

Filby, R.H., Van Berkel, G.J., Bragg, A.E., Joubert, A., Robison, W.E., Gromm, C.A., (1985), Evaluation of residual fuel oil standards - Reference materials as trace elements standards, Journal of Radioanalytical and Nuclear Chemistry,91/2: 361-368.

Gregoire, D. C., Miller-Ihili, N. J., Sturgeon, R. E., (1994) Direct Analysis of Solids by Ultrasonic Slurry Electrothermal Vaporization Inductively Coupled Plasma M ass Spectrometry. J. Analyt. Atomic Spectrometry, 9: 605-610.

Hopke, P. K. (1985) Receptor Modeling In Environmental Chemistry. Wiley, New York.

Joseph, J. (1988) The Chemical Characterization of Airborne Particles Released by Three West Virginia Coal-Fired Power Plants for Receptor Model Studies. Masters Thesis. University of Maryland.

Kidwell, C.B., Ondov, J.M. (2001). Development and Evaluation of a Prototype System or Collecting Sub-Hourly Ambient Aerosol for Chemical Analysis. Aerosol Sci Tech, 35. 596-601.

Kidwell, C.B., Ondov, J.M. (2004). Elemental Analysis of Sub-Hourly Ambient Aerosol Collections. Aerosol Sci Tech, 38. 205-18.

Miller, S. J., Ness, S. R., Weber, F. G., Erickson, T. A., Hassett, D. J., Hawthorne, S. B., Katrinak, K. A., Louie, P. K. K., eneragy \& Environmental Research center, University of N. Dakota, Grand Forks, North Dakota, (1996). A Comprehensive Assessment of Toxic emissions From Coal-Fired Power Plants: Phase I Results from the U. S. Department of Energy Study.

Mroz, E. J.,(1976) The Study of the Elemental Composition of Particulate Emission from an OilFired Power Plant. Ph.D. Thesis. University of Maryland.

Olmez, I., Sheffield, A. E., Gordon, G. E., Houck, J. E., Prichett, L. C., Cooper, J. A., Dzubay, T. G., Bennett, R. L. (1988). JAPCA 38:1392-1402.

Ondov, J.M., Ragaini, R.C., Biermann, A.H. (1979) Elemental Emissions from a CoalFired Power Plant. Comparison of a Venturi Wet Scrubber System with a Cold-Side Electrostatic Precipitator. Environ. Sci. \& Tech. 13. 598-606. 
Ondov, J.M., Ragaini, R.C., Biermann, A.H. (1979) Emissions and Particle-Size Distributions of Minor and Trace Elements at Two Western Coal-Fired Power Plants Equipped with Cold-Side Electrostatic Precipitators. Environ. Sci. \& Tech 13. 946-953.

Ondov, J. M., Biermann, A. H., Heft, R. E, Koszykowski (1981). ACS Symposium Series, No. 167, Atmospheric Aerosol: Source/Air Quality Relationships, E. S. Macias and P. K., Hopke, editors, American Chemical Society.

Ondov, J.M., Choquette, Ce.E., Zoller, W.H., Gordon, G.E., Biermann, A.H., and Heft, R.E., (1989). Atmospheric Behavior of Trace Elements on Particles Emitted from a Coal-Fired Power Plant. Atmos. Environ. 23:2193-2204.

Ondov, J.M., Wexler, A.S. (1998). Where Do Particulate Toxins Reside? An Improved Paradigm for the Structure and Dynamics of the Urban Mid-Atlantic Aerosol. Environ. Sci. Technol, 32. 2547-55.

Paatero, P., Tapper, U. (1994). Positive matrix factorization: a non-negative factor model with optimal utilization of error estimates of data values. Enviornmentrics 5, 111-126.

Paatero, P. (1997). Least squares formulation of robust non-negative factor analysis. Chemometerics and Intelligent Laboratory Systems 37, 23-35.

Pancras, J.P., Ondov, J.M., Zeisler, R. (2005). Multi-element electrothermal AAS determination of 11 marker elements in fine ambient aerosol slurry samples collected with SEAS-II. Analytica Chimica Acta, 538. 303-12.

Pancras, J.P.,(2006). Identification of sources and estimation of emission profiles from highly time-resolved pollutant measurements in Tampa, FL. Atmospheric Environment, 40. S467-81.

Pancras, J. P. (2008). Unpublished data from draft Manuscript, private communication.

Park, S. S., Kleissl, J., Harrison, D., Nair, N.P., Kumar, V., Adam, M., Ondov, J.M., Parlange, M. (2006) Characteristics of $\mathrm{PM}_{2.5}$ Episodes Revealed by Semi-Continuous Measurements at the Baltimore Supersite at Ponca St., Aerosol Sci Tech, 40. 845-60.

Park, S. S., Pancras P. J., Ondov, J. M., Poor, N. (2005) A New Pseudo-deterministic Multivariate Receptor Model for Accurate Individual Source Apportionment Using Highly Time-resolved Ambient Concentrations, J. Geophys. Res., 110, No. D7,1 6 April. Citation no. D07S15

Park, S.S., Pancras, J.P., Ondov, J.M., Robinson, Allen. (2006). Application of the Pseudo-Deterministic Receptor Model to resolve Power Plant Influences on Air Quality in Pittsburgh, Aerosol Sci. Technol. 40:883-897

Santos, M., C., Nobrega, J. A. (2006). Slurry Nebulization in Plasmas for Analysis of Inorganic Materials, Applied Spectroscopy Reviews, 41, 427-448.

Weitkamp, E. A., Lipsky, E. M., Pancras, J. P., Ondov, J. M., Polidori, A., Turpin, B. J., and Robinson, A. L. (2005) ."Fine Particle Emission Profile for a Large Coke Production Facility Based on Highly Time- Resolved Fence Line Measurements," Atmospheric Environment, 39:6719-6733.

U. S. Environmental Protection Agency. http://www.epa.gov/airmarkets/emissions/index.html U. S. Environmental Protection Agency. National Emission Inventory (2002 data), http://www.epa.gov/ttn/chief/net/2002inventory.html.

U. S. Environmental Protection Agency, Report on emission factors for fuel-oil fired power plants. Title unavailable. http://www.epa.gov/ttn/chief/ap42/ch01/final/c01s03.pdf 


\section{APPENDIX A}

AIR POLLUTION SOURCES IN THE TAMPA-SYDNEY AREA

\begin{tabular}{|c|c|c|c|c|c|c|c|c|}
\hline \multirow[b]{2}{*}{ Sources } & \multirow[b]{2}{*}{ Facility Name } & \multirow{2}{*}{$\begin{array}{c}\text { From } \\
\text { Sydney } \\
\text { Dist. (km) }\end{array}$} & \multirow{2}{*}{ Degrees } & \multicolumn{5}{|c|}{ ARMS Potential Emissions (tons per year) } \\
\hline & & & & Co & NOX & PM & SO2 & VOC \\
\hline \multirow[t]{2}{*}{1} & TECO Big Bend & 24.7 & 220 & 3024 & 82622 & 7591 & 364178 & 585 \\
\hline & Piney Point Fertilizer & 46.8 & 219 & 0 & 44 & 0 & 1278 & 0 \\
\hline $2 \mathbf{a}$ & Tropicana & 62.0 & 211 & 231 & 1358 & 615 & 317 & 41 \\
\hline $2 b$ & Delta Asphalt & 13.4 & 329 & 28 & 38 & 51 & 31 & 35 \\
\hline \multirow[t]{7}{*}{3} & TECO Gannon & 20.0 & 251 & 1401 & 79088 & 6267 & 126940 & 149 \\
\hline & National Gypsum & 32.1 & 250 & 62 & 109 & 172 & 347 & 2 \\
\hline & IMC Agrico Pt Sutton & 18.6 & 250 & 9 & 0 & 383 & 0 & 0 \\
\hline & Pop's Painting & 17.2 & 250 & 0 & 0 & 38 & 0 & 10 \\
\hline & Southdown Pendola Pt & 20.8 & 251 & 0 & 0 & 33 & 0 & 0 \\
\hline & Holnam Pt Sutton & 20.5 & 251 & 0 & 0 & 29 & 0 & 0 \\
\hline & Pakhoed & 17.9 & 248 & 0 & 0 & 21 & 0 & 0 \\
\hline \multirow[t]{7}{*}{4} & Gulf Coast Recycling & 15.0 & 269 & 0 & 0 & 26 & 0 & 0 \\
\hline & Mckay Bay & 18.8 & 265 & 209 & 2059 & 172 & 1461 & 79 \\
\hline & Overstreet Paving & 53.2 & 262 & 0 & 39 & 25 & 40 & 35 \\
\hline & International Ship & 21.0 & 267 & 19 & 89 & 147 & 6 & 271 \\
\hline & Lafarge Maritime & 21.5 & 261 & 0 & 0 & 324 & 0 & 0 \\
\hline & Conagra & 22.0 & 266 & 0 & 0 & 99 & 0 & 0 \\
\hline & Sonny Glasbrenner & 45.4 & 260 & 0 & 24 & 23 & 0 & 0 \\
\hline \multirow[t]{8}{*}{5} & FPC Higgins & 42.7 & 276 & 1462 & 10027 & 1260 & 24804 & 478 \\
\hline & Metal Industries & 42.9 & 280 & 0 & 0 & 18 & 0 & 0 \\
\hline & Conrad Yelvington & 17.5 & 280 & 0 & 0 & 27 & 0 & 0 \\
\hline & Chromalloy & 30.6 & 282 & 0 & 0 & 32 & 0 & 2 \\
\hline & Southern Crushing & 15.4 & 286 & 0 & 0 & 0 & 1 & 0 \\
\hline & Johnson Controls & 20.9 & 294 & 0 & 1 & 110 & 0 & 0 \\
\hline & Champeau Recycling & 43.1 & 305 & 0 & 0 & 49 & 0 & 0 \\
\hline & Coniglio & 14.4 & 316 & 0 & 49 & 24 & 1 & 0 \\
\hline \multirow[t]{10}{*}{6} & FPC Bartow & 38.3 & 253 & 689 & 8819 & 2600 & 57223 & 182 \\
\hline & Tampa Ship & 21.5 & 257 & 40 & 188 & 19 & 12 & 373 \\
\hline & Unocal & 21.3 & 255 & 0 & 0 & 15 & 12 & 0 \\
\hline & Nitram & 17.2 & 254 & 0 & 302 & 210 & 1 & 1 \\
\hline & Chemical Lime of Alabame & 21.5 & 255 & 0 & 0 & 67 & 0 & 0 \\
\hline & Eastern Associated & 19.4 & 255 & 0 & 0 & 264 & 0 & 0 \\
\hline & $\operatorname{cs} X$ & 17.3 & 254 & 0 & 0 & 242 & 0 & 0 \\
\hline & Sludge Dryer & 15.6 & 254 & 0 & 0 & 52 & 0 & 47 \\
\hline & APAC & 20.0 & 253 & 0 & 0 & 38 & 0 & 58 \\
\hline & West Coast Concrete & 48.4 & 253 & 0 & 0 & 57 & 0 & 0 \\
\hline \multirow[t]{4}{*}{7} & Cargill Fertilizer & 19.7 & 235 & 22 & 176 & 288 & 5931 & $\begin{array}{l}0 \\
0\end{array}$ \\
\hline & FPC Bayboro & 46.1 & 241 & 0 & 0 & 0 & 6848 & 0 \\
\hline & Janet \& Charles Recyclino & 18.0 & 242 & 0 & 200 & 100 & 0 & 0 \\
\hline & Reed Minerals & 18.7 & 244 & 0 & 0 & 31 & 0 & 0 \\
\hline 8 & FPL Manatee & 41.5 & 196 & 0 & 22732 & 9472 & 83351 & 0 \\
\hline 9 & Background & - & - & - & - & - & - & - \\
\hline
\end{tabular}

Source: Florida Department of Environmental Protection Air Management System (database). 


\section{APPENDIX B RESULTS OF SAMPLE PREPARATION STUDIES}

\section{B.1 Test slurries}

Three test slurries were used for methods development i) an interim standard reference material (iSRM) consisting of urban particulate matter (UPM) being certified by the National Institute of Standards (NIST; Gaithersburg, MD; Zeisler, 200?) and two composites prepared from actual atmospheric samples collected with the University of Maryland Semi-continuous Elements in Aerosol Sampler (SEAS) at ii) an industrial area near Birmingham, AL, and iii) near a coke production plant in Pittsburgh (ref). The NIST iSRM was chosen to represent typical urban PM and serves as a convenient reference material and will be available from NIST. The Birmingham and Coke slurries contained high concentrations of different sets of metals: the former contained more refractory materials; whereas the latter contained high concentrations of soot and organic matter and, together, represent the extremes of difficult matrices that we have encountered.

The iSRM test slurry was prepared by sonicating $150 \mathrm{mg}$ of the NIST SRM in $500 \mathrm{~mL}$ of 18.2 $\mathrm{M} \Omega-\mathrm{cm}$ water. Actual atmospheric slurry samples collected with SEAS-II contain few particles $>2 \mu \mathrm{m}$. However, the geometric mean size of particles in the iSRM is reported to be zzz $\mu \mathrm{m}$. Therefore, a $5.0 \mu \mathrm{m}$-pore Teflon membrane filter was used to remove particles larger than the pore size. Five filters were needed for this process. The filtrate was divided into two aliquots, and acidified to 0.2 and $2.0 \%$, respectively, of high purity nitric acid. In addition to the filtrate (iSRM test slurry), the filters with their attached particles and 5 blank filters were also saved for elemental analyses described below.

The SEAS-II slurry samples used in this study were stored frozen, in their polypropylene collection vials. These were thawed and used directly to prepare the composite test slurries. The coke-oven slurry was prepared by mixing selected samples collected in the plume of a coke oven near Pittsburgh (), to produce a total volume of $\sim 100 \mathrm{~mL}$. Likewise, $\sim 150 \mathrm{~mL}$ of Birmingham slurry was produced by combining SEAS slurry samples shown previously to contain high concentrations (give range) of many elements.

Each of the three test slurries contained soot and refractory particles which can settle and fail to be aspirated into the ICPMS, lost to the walls of the transfer tubing (especially in the peristaltic pump), or fail to be totally ionized in the plasma, thus resulting in low analytical results, i.e., low analytical yield. Therefore, to evaluate analytical yields of the subsequent slurry treatment methods, total digestions were performed using concentrated acids, where practical, i.e. on the iSRM-UPM and Birmingham composite slurry. The quantity of coke-plant slurry was insufficient to permit both slurry and total digestion analyses. 
Table A1 contains the percent yields of the average slurry concentrations, determined with the adopted sample treatment method, to the averaged slurry concentrations obtained in the total digestion. The adopted method of 2 days heating in $0.2 \% \mathrm{HNO}_{3}$ increases the yield of $\mathrm{Fe}$ by $11 \%$ and of $\mathrm{Al}, \mathrm{Bi}, \mathrm{Ca}, \mathrm{Ce}, \mathrm{Co}, \mathrm{Cr}, \mathrm{La}, \mathrm{Mg}, \mathrm{Mo}, \mathrm{Ni}$, and $\mathrm{U}$ by $4-8 \%$. While percent recoveries remain near 50\% for elements such as $\mathrm{Al}, \mathrm{Sr}$, and $\mathrm{Ti}$, as heating times are increased, leaching of $\mathrm{Al}, \mathrm{Ca}$, $\mathrm{Mg}$, and Ti becomes an increasing problem in blank values, with large concentration differences from vial to vial, compromising standard deviations.

\begin{tabular}{|c|c|c|c|c|c|c|c|}
\hline & \multicolumn{2}{|c|}{$\begin{array}{l}\text { Unheated } \\
\text { Samples }\end{array}$} & \multicolumn{2}{|c|}{$\begin{array}{c}\text { Samples } \\
\text { Heated } 1 \text { Day }\end{array}$} & \multicolumn{2}{|c|}{$\begin{array}{c}\text { Samples Heated } \\
2 \text { Days }\end{array}$} & \multirow[t]{2}{*}{$\begin{array}{c}\% \\
\text { Increase }\end{array}$} \\
\hline & $\mathbf{x}$ & $\mathbf{s}$ & $\mathbf{x}$ & $\mathbf{s}$ & $\mathbf{x}$ & $\mathbf{s}$ & \\
\hline $23 \mathrm{Na}$ & 0.93 & 0.04 & 0.92 & 0.04 & 0.93 & 0.04 & 0 \\
\hline $24 \mathrm{Mg}$ & 0.90 & 0.04 & 0.90 & 0.07 & 0.93 & 0.04 & 4 \\
\hline 27Al & 0.48 & 0.16 & 0.51 & 0.17 & 0.53 & 0.18 & 5 \\
\hline $39 K$ & 0.95 & 0.05 & 0.95 & 0.05 & 0.97 & 0.05 & 2 \\
\hline $44 \mathrm{Ca}$ & 0.51 & 0.10 & 0.56 & 0.11 & 0.57 & 0.12 & 6 \\
\hline 47Ti & 0.37 & 0.48 & 0.36 & 0.47 & 0.36 & 0.47 & -1 \\
\hline $51 \mathrm{~V}$ & 0.88 & 0.09 & 0.86 & 0.08 & 0.88 & 0.05 & 0 \\
\hline $52 \mathrm{Cr}$ & 0.60 & 0.02 & 0.59 & 0.01 & 0.64 & 0.02 & 4 \\
\hline $55 \mathrm{Mn}$ & 0.90 & 0.02 & 0.90 & 0.01 & 0.91 & 0.02 & 1 \\
\hline $56 \mathrm{Fe}$ & 0.64 & 0.03 & 0.71 & 0.01 & 0.74 & 0.02 & 11 \\
\hline $59 \mathrm{Co}$ & 0.72 & 0.09 & 0.74 & 0.09 & 0.78 & 0.10 & 6 \\
\hline $60 \mathrm{Ni}$ & 0.92 & 0.24 & 0.95 & 0.25 & 1.00 & 0.26 & 8 \\
\hline $63 \mathrm{Cu}$ & 0.89 & 0.07 & 0.88 & 0.07 & 0.90 & 0.07 & 0 \\
\hline $66 Z n$ & 0.90 & 0.02 & 0.89 & 0.01 & 0.89 & 0.01 & -1 \\
\hline 75As & 0.85 & 0.06 & 0.87 & 0.05 & 0.89 & 0.05 & 3 \\
\hline $78 \mathrm{Se}$ & 0.89 & 0.14 & 0.94 & 0.23 & 0.94 & 0.14 & 5 \\
\hline $88 \mathrm{Sr}$ & 0.44 & 0.19 & 0.45 & 0.19 & 0.42 & 0.18 & -2 \\
\hline 95Mo & 0.92 & 0.05 & 0.92 & 0.06 & 0.96 & 0.06 & 4 \\
\hline $111 \mathrm{Cd}$ & 0.89 & 0.05 & 0.90 & 0.10 & 0.90 & 0.05 & 1 \\
\hline $121 \mathrm{Sb}$ & 1.16 & 0.33 & 1.16 & 0.34 & 1.17 & 0.34 & 1 \\
\hline 137Ba & 0.96 & 0.04 & 0.97 & 0.05 & 0.94 & 0.04 & -2 \\
\hline 139La & 1.03 & 0.23 & 0.99 & 0.21 & 1.07 & 0.24 & 4 \\
\hline $140 \mathrm{Ce}$ & 0.76 & 0.10 & 0.78 & 0.10 & 0.81 & 0.10 & 6 \\
\hline $147 \mathrm{Sm}$ & 1.35 & 0.71 & 1.24 & 0.61 & 1.36 & 0.68 & 1 \\
\hline $208 \mathrm{~Pb}$ & 0.87 & 0.02 & 0.87 & 0.02 & 0.88 & 0.02 & 0 \\
\hline 209Bi & 0.90 & 0.02 & 0.91 & 0.03 & 0.95 & 0.03 & 4 \\
\hline $238 U$ & 0.78 & 0.11 & 0.80 & 0.09 & 0.85 & 0.12 & 7 \\
\hline
\end{tabular}




\section{APPENDIX C \\ Hybrid GFAAZ-ICPMS Data Set}
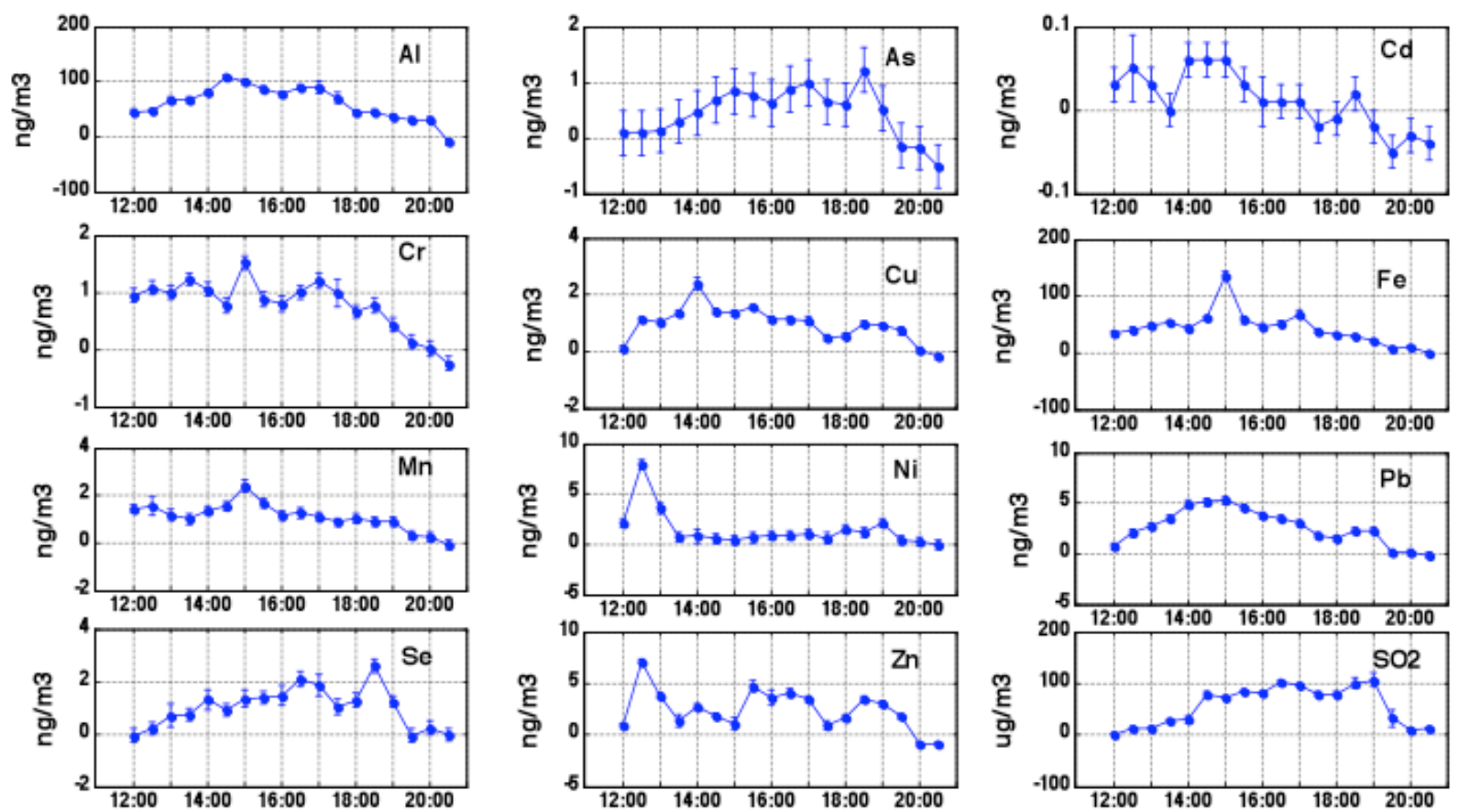


\section{APPENDIX D \\ NEI, $\mathrm{X}_{0}$ s, and Upper- and Lower-Bounds Used in PDRM Runs}

\begin{tabular}{|c|c|c|c|c|c|c|c|c|c|c|c|c|c|c|c|c|c|c|}
\hline \multicolumn{3}{|c|}{ NEI Emission Rates, g/s (2002) } & \multirow{3}{*}{$\begin{array}{c}\text { Cargill } \\
\mathrm{g} / \mathrm{s}\end{array}$} & \multirow{3}{*}{$\begin{array}{c}\text { Gannon } \\
\mathrm{g} / \mathrm{s}\end{array}$} & \multirow{3}{*}{$\begin{array}{c}\text { Bartow } \\
\mathrm{g} / \mathrm{s}\end{array}$} & \multirow{3}{*}{$\begin{array}{l}\text { Gulf Coast } \\
\mathrm{g} / \mathrm{s}\end{array}$} & \multicolumn{6}{|c|}{ Upper and Lower Emission Rate Bounds entered into PDRM ( $\mathrm{g} / \mathrm{s}$ ) } & & & \\
\hline & Manatee & Big Bend & & & & & \multicolumn{2}{|c|}{ Manatee } & \multicolumn{2}{|c|}{ Big Bend } & \multicolumn{2}{|c|}{ Cargill } & & & & & & \\
\hline & $\mathrm{g} / \mathrm{s}$ & $\mathrm{g} / \mathrm{s}$ & & & & & lb & ub & lb & ub & lb & ub & \multicolumn{2}{|c|}{ Ib Gannon } & \multicolumn{2}{|c|}{ 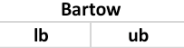 } & \multicolumn{2}{|c|}{$\begin{array}{l}\text { Gulf Coast } \\
\text { lb } \quad \text { ub }\end{array}$} \\
\hline Al & - & - & - & - & - & - & $*$ & * & * & * & * & * & ${ }^{*}$ & $*$ & * & * & * & * \\
\hline As & 0.00794133 & $1.9303 \mathrm{E}-05$ & $1.15 \mathrm{E}-06$ & $1.502 \mathrm{E}-05$ & 0.002332 & 0.00055 & 0.000915 & 0.0125 & 0.00491 & 0.0589 & $1.04 \mathrm{E}-06$ & $1.27 \mathrm{E}-06$ & 0.00921 & 0.066 & 0.000162 & 0.0225 & 0 & 0.0249 \\
\hline Cd & 0.00239442 & 0.00862984 & $7.71 \mathrm{E}-06$ & 0.0015148 & 0.000708 & 0.00046 & 0.002155 & 0.047 & 0.00135 & 0.009493 & $6.94 \mathrm{E}-06$ & $8.48 \mathrm{E}-06$ & 0.001363 & 0.001666 & 0.000637 & 0.000778 & 0 & 0.000501 \\
\hline $\mathrm{Cr}$ & U.U0su8sb8 & $0.0106 / 336$ & $8.8 \mathrm{t}-06$ & 0.009624 & 0.002128 & 0.00046 & $0.0045 / 3$ & 0.114 & 0.009606 & 0.018 & $1.92 \mathrm{t}-\mathrm{Ub}$ & y.68t-06 & 0.008662 & U.01L & 0.00191ל & U.U2 & $0.00041 /$ & 0.0013 \\
\hline $\mathrm{Cu}$ & - & - & - & - & - & - & $*$ & $*$ & $*$ & $*$ & $*$ & $*$ & $*$ & $*$ & $*$ & $*$ & $*$ & $*$ \\
\hline $\mathrm{Fe}$ & - & - & - & - & - & - & $*$ & $*$ & $*$ & $*$ & $*$ & $*$ & $*$ & $*$ & $*$ & $*$ & $*$ & $*$ \\
\hline $\mathrm{Mn}$ & 0.01896306 & - & $8.8 \mathrm{E}-06$ & 0.0181661 & 0.011564 & 0.00246 & 0.008 & 1.152 & 0.013 & 0.202 & 7.92E-06 & $9.68 \mathrm{E}-06$ & 0.016349 & 0.019983 & 0.010407 & 0.01272 & 0.002217 & 0.00271 \\
\hline $\mathrm{Ni}$ & 0.5083664 & 0.02947217 & $1.53 \mathrm{E}-05$ & 0.0103631 & 0.226836 & 0.00115 & 0.45753 & 1.9 & 0.026525 & 0.032419 & $1.38 \mathrm{E}-05$ & $1.68 \mathrm{E}-05$ & 0.009327 & 0.011399 & 0.023 & 2.268 & 0.001031 & 0.00126 \\
\hline $\mathbf{P b}$ & 0.00908962 & 0.0235081 & $5.0 \mathrm{E} 06$ & 0.0155547 & 0.038013 & 0.03634 & 0.008181 & 0.116 & 0.004 & 0.088 & 4.54E 06 & $5.55 \mathrm{E} 06$ & 0.009 & 0.116 & 0.016 & 0.346 & 0.03271 & 0.039979 \\
\hline Se & $0.0044246 G$ & 0.04708496 & $8.63 \mathrm{E}-08$ & 0.0481181 & 0.001473 & 0.00023 & 0.003982 & 2 & 0.026 & 0.051793 & $7.77 \mathrm{E}-08$ & 9.49E-08 & 0.043306 & 0.05293 & 0.001325 & 0.00162 & 0.000200 & 0.000252 \\
\hline $\mathrm{Zn}$ & - & - & - & - & - & - & $*$ & $*$ & $*$ & $*$ & $*$ & $*$ & $*$ & $*$ & $*$ & " & $*$ & $*$ \\
\hline $\mathrm{Ag}$ & - & - & - & - & - & - & * & * & * & * & * & * & * & * & * & * & * & * \\
\hline $\mathrm{Ba}$ & - & - & - & - & - & - & * & * & * & * & * & * & * & * & $*$ & * & * & * \\
\hline Co & 0.03621734 & - & $4.29 \mathrm{E}-06$ & 0.0036966 & 0.011316 & $2.8767 \mathrm{E}-08$ & 0.032596 & 0.039839 & 0.003255 & 0.012 & $3.86 \mathrm{E}-06$ & $4.71 \mathrm{E}-06$ & 0.003327 & 0.004066 & 0.006 & 0.012448 & $2.59 \mathrm{E}-08$ & $3.16 \mathrm{E}-08$ \\
\hline La & - & - & - & - & - & - & $*$ & $*$ & $*$ & $*$ & * & $*$ & $*$ & $*$ & $*$ & $*$ & $*$ & $*$ \\
\hline Sb & 0.03158493 & 0.00065408 & - & 0.0001843 & 0.00987 & 0.0012 & 0.028426 & 0.034743 & 0.000589 & 0.002 & $*$ & $*$ & $9.21 \mathrm{E}-05$ & 0.000276 & 0.004934 & 0.014801 & 0.000608 & 0.001823 \\
\hline v & - & - & - & - & - & - & $*$ & $*$ & $*$ & * & * & $*$ & $*$ & $*$ & $*$ & $*$ & $*$ & $*$ \\
\hline w & & & & & & & * & * & $*$ & * & * & $*$ & * & * & * & * & * & * \\
\hline $\mathrm{Ca}$ & - & - & - & - & - & - & $*$ & $*$ & $*$ & $*$ & * & $*$ & $*$ & $*$ & $*$ & $*$ & $*$ & * \\
\hline$\kappa$ & - & - & - & - & - & - & $*$ & * & $*$ & * & " & " & $*$ & $*$ & $*$ & " & " & "* \\
\hline Mg & - & - & - & - & - & - & * & * & * & * & * & * & * & * & * & ${ }^{*}$ & * & * \\
\hline $\mathrm{Na}$ & - & - & - & - & - & - & * & * & * & * & * & * & * & * & * & * & * & * \\
\hline $\mathrm{Sr}$ & - & - & - & - & - & - & $*$ & * & * & * & * & $*$ & * & * & * & * & * & * \\
\hline PM & 74.8 & 49.1 & 1.7 & 92.2 & 13.3 & 0.15 & - & - & - & - & - & - & - & - & - & - & - & - \\
\hline & *- entered as & 0.0001 and 50 & $\mathrm{~g} / \mathrm{s}$ for Lowe & and Upper B & ounds, resp & tively & & & & & & & & & & & & \\
\hline
\end{tabular}




\section{APPENDIX E \\ NEI, $X_{0} s$, and Upper- and Lower-Bounds Used in PDRM Runs}

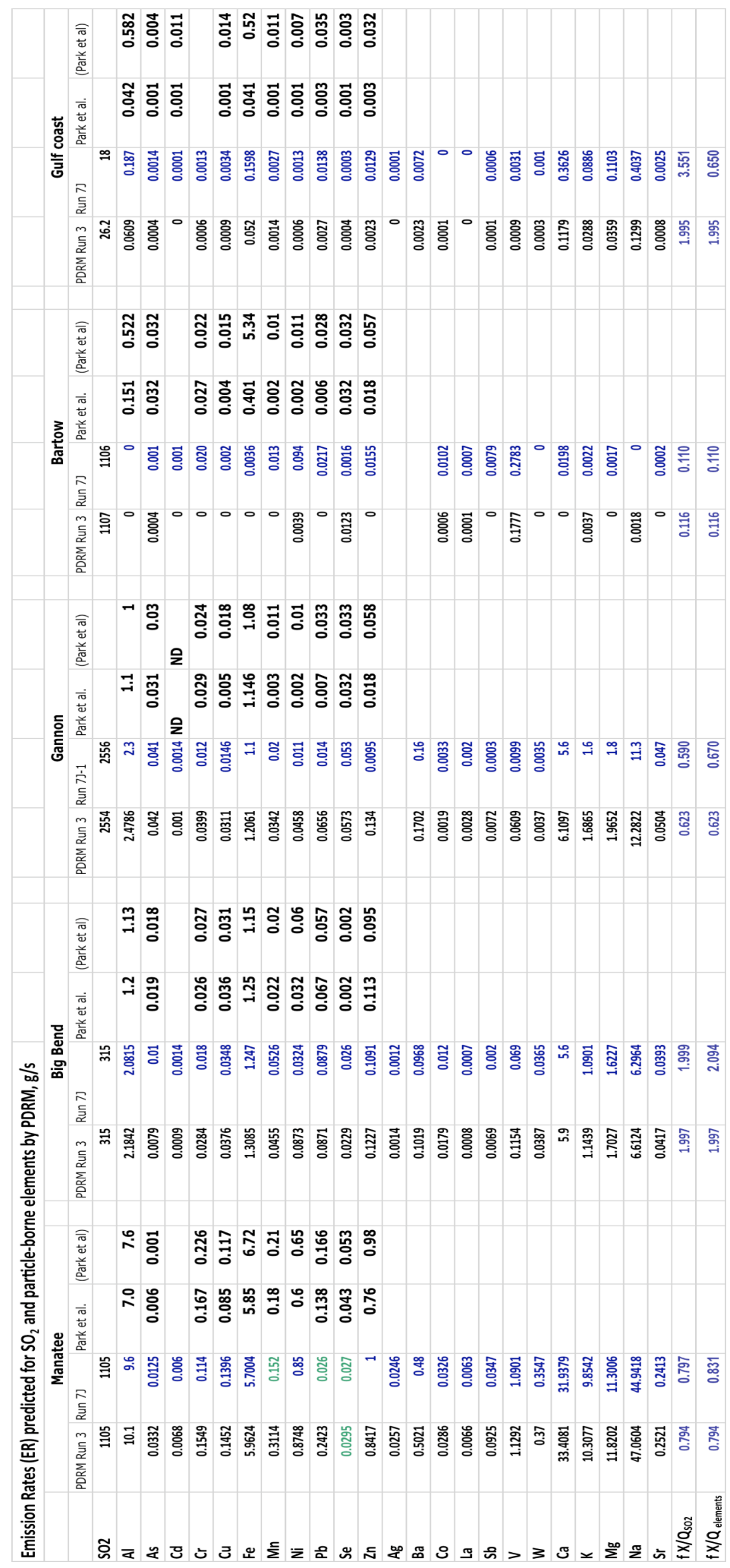

